\title{
Dーマンニトールを原料とするキラル ビルディングブロックの合成
}

\author{
高 野 誠 一**小笠原 国 郎* \\ Synthesis of Versatile Chiral Building Blocks Starting from D-Mannitol. \\ Seiichi Takano* and Kunio Ogasawara*
}

\begin{abstract}
This article describes a compilation of recent development in the practical preparation of versatile chiral building blocks carried out in the authors' laboratories using D-mannitol as common chiral starting material. The described examples are accompanied by full experimental details for the practical purpose.
\end{abstract}

\section{1. はじめに}

生理活性から液晶にわたるまでそれらの特性の発現が 分子の不斉によって左右される事実が認識され，もはや キラリティー制御を前提としない合成計画は考えられな くなった。分割法を別にすれば不斉分子の構築は（i ) 既 存不斉分子からの変換, (ii)不斉補助剂の使用, (iii)不 斉誘起触媒の使用, という 3 つの方法に依存している が, 不斉補助剤あたり化学量論量の不斉分子の産生にし か対応しない第 2 の手法には実用的に限界があり, 酵素 法, 化学触媒法の別なく効率性の高い第 3 の手法および 活用次第で極めて効率性の高い第 1 の手法が今後の主流 となると思われる。いずれにせよ近い将来には手法を問 わず種々の不斉分子種の入手は日常的に行われ得ること になり，これらを如何に効率的に多様の構造を持つ対象 物の組み立てに対応させるかが合成化学者の課題となる ものと思われる。我々はこれまで第 1 の観点から入手容 易な $\mathrm{D}$-マンニトール(1)をキラル資源として有効に活 用することを目的として，これより生理活性天然物を中 心とするキラル合成を行ってきた1)。この際多様の適応 性を見出すために Dーマンニトール（1）それ自身を直接 対象物に適合させることは避け，一たん機能性の高いキ ラルビルディングブロックに変換した後，これらの機能 性をもとに多様の目的物に適応させるものとした。この 間， $\mathrm{D}^{-}$マンニトール（1）の持つ $\mathrm{C}_{2}$-対称性がこの目的に

*東北大学薬学部薬品合成化学教室

* Pharmaceutical Institute, Tohoku University
効果的に反映され基本キラル原料として極めて有効に機 能することが判ってきた。これまでのところ我々の検討 はマンニトール(1) 分子の $\mathrm{C}_{2}$-対称性に基づいてこれを キラルグリセロール二量体, 即ちキラルグリセロール誘 導体としての活用範囲に限定されるものであるが，それ にもかかわらず多くの有用なキラルビルディングブロッ クを効果的に作り出すことが出来た。最近キラルグリセ ロール単位が䤉素法”あるいは化学触媒法 ${ }^{3)}$ によって効 果的に合成されるようになってきて扔り，我々の結果は これら第 3 の手法と連結出来るものと考えている。本稿 は我々がこの間に得た結果を述べるものであるが, 特定 の対象物のキラル合成をそれぞれ示すものではなく，こ の間に得られた多様の化合物の構築に広い適用性を持つ と思われる量的合成が可能なキラルビルディングブロッ クを拾い集めて実施例によって示し，今後この種の化合 物を取り扱われる方々の参考に供することを目的とする ものである。従って記載した例はすべて我々の手によっ て試みた結果のみに限定されるものであり, 多くの優れ た例が欠けていることを了承頂きたい4)。さらに参考文 献についても実施例の記載されているもののみを示した のでさらに詳しくは原報を参照されたい。

スキーム 1 は本論文に記載したキラルビルディングブ ロック類を D-マンニトール（1）から抒よよの世代順 に要約したものである。このなかにはいくつか既存の化 合物も含まれるが製法的に改善がなされているものを示 した。

\section{2. 基本原料の合成}

基本原料としては $1,2: 5,6$ - di- $O$-isopropylidene-D- 


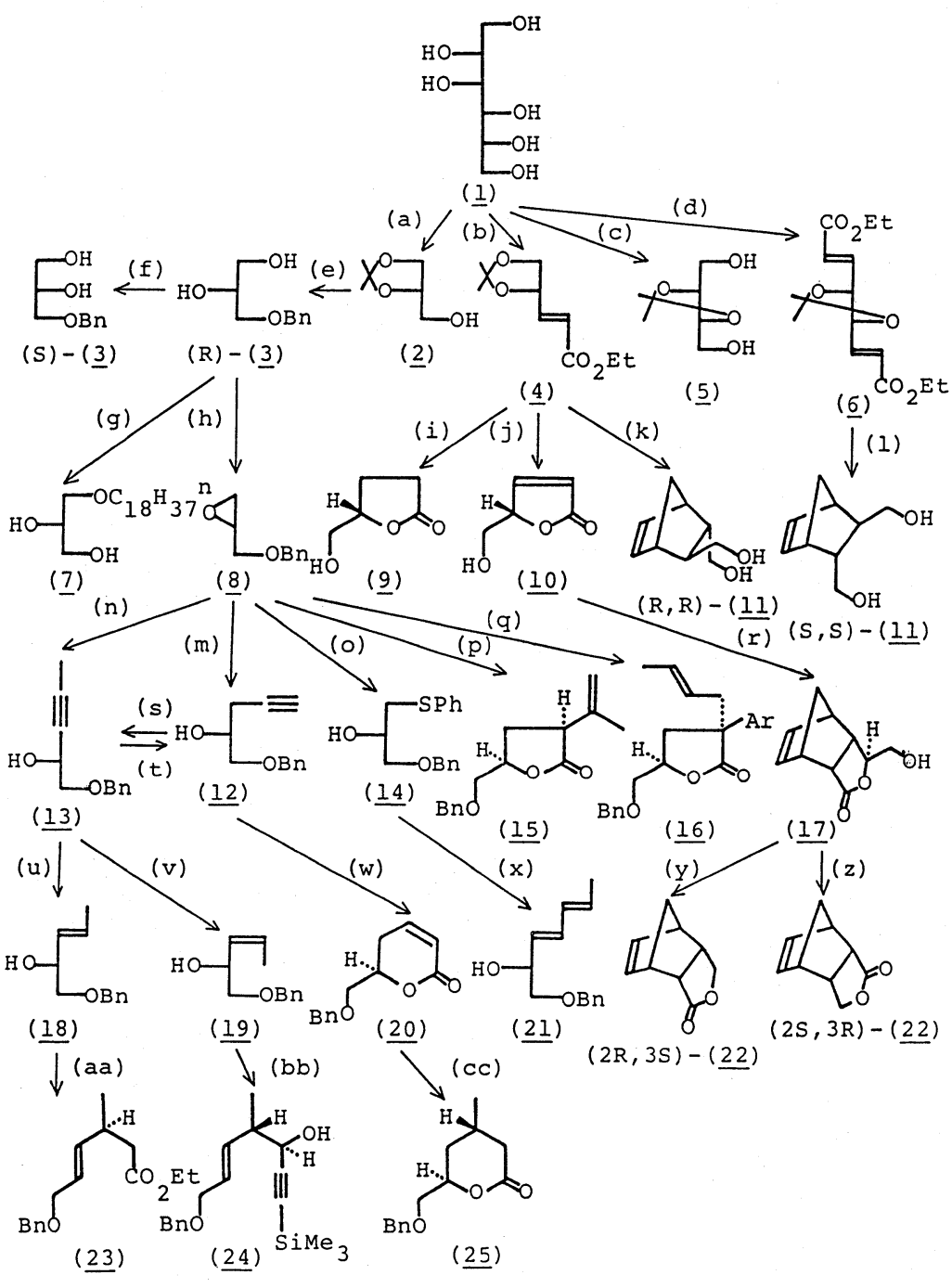

\section{Scheme 1}

mannitol(26) および 3,4-O-isopropylidene-D-mannitol (28)の 2 種を用いた。前者は $D^{-}$- mannitol $(1$ )の部分アセ トニド化占によって，また後者は $1,2: 3,4: 5,6$-tri- $O$ isopropylidene-D-mannitol ${ }^{6)}(27)$ の形成と, つづく部分加 水分解》によって得られる。前者の大量合成については D-mannitol（１）の溶解性などから若干問題点を残し，い くつかの改良法も報告されているが8)，我々の試みた範 囲ではアセトン中無水塩化亜鉛を用いる $\mathrm{Baer}^{5)} ら の$ 最も 古い方法が数百グラムスケールで最良の結果を与えた。 一方, 後者については困難なく行うことが出来る ( ス キーム 2 )。

1, $2: 5,6$ - Di-O-isopropylidene-D-mannitol ${ }^{5)}(26)$ 無水 $\mathrm{ZnCl}_{2} 400 \mathrm{~g}(2.93 \mathrm{~mol})$ をアセトン $(2.51)$ に懸濁
させ防湿下に室温で攪拌しこれに D-mannitol( 1 ) $250 \mathrm{~g}(1.375 \mathrm{~mol})$ を反応液が $20^{\circ} \mathrm{C}$ 以上にならないよ うに氷冷下に加之 $24 \mathrm{~h}$ 攪挥する。反応液に $\mathrm{K}_{2} \mathrm{CO}_{3} 400 \mathrm{~g}(2.5 \mathrm{~mol})$ の水溶液 $(500 \mathrm{ml})$ を加え十分に 攪拌してから，有機層を傾瀉でわけ，さらに沈澱物 は $\mathrm{CH}_{2} \mathrm{Cl}_{2}$ で十分に洗浄する。アセトン層に conc. $\mathrm{NH}_{4} \mathrm{OH}($ ca. $5 \mathrm{ml})$ を加え, $40^{\circ} \mathrm{C}$ 以下で減圧濃縮し, 残査を $\mathrm{CH}_{2} \mathrm{Cl}_{2}$ 洗液に溶かし分離する水層を分け る。有機層を冷水で洗浄し, 乾燥 $\left(\mathrm{K}_{2} \mathrm{CO}_{3}\right)$ 後, 溶媒 を減圧留去し, 残留物を $\mathrm{CH}_{2} \mathrm{Cl}_{2}$ より再結晶し diacetonide(26) $214.8 \mathrm{~g}(60 \%)$ を得る：mp $119-121^{\circ} \mathrm{C} 。$ 3, 4- O-Isopropylidene-D-mannitol ${ }^{6,7)}(28) \quad \mathrm{D}$ mannitol ( 1$) 20 \mathrm{~g}(0.11 \mathrm{~mol})$ の acetone $(250 \mathrm{ml})$ 懸濁液 


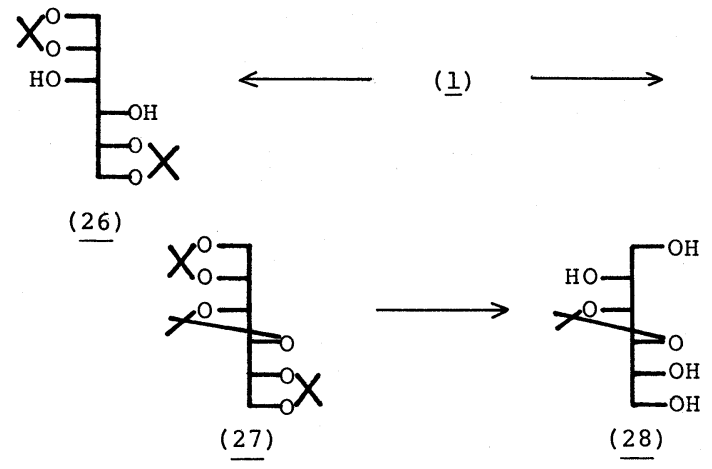

Scheme 2

に室温攪汼下に conc. $\mathrm{H}_{2} \mathrm{SO}_{4}(2 \mathrm{ml})$ を加え, D-mannitol（1)が完全に溶解するまで攪拌を続ける( $24 \mathrm{~h})$ 。水冷攪找下に $\mathrm{K}_{2} \mathrm{CO}_{3}(10 \mathrm{~g})$ の水溶液 $(10 \mathrm{ml})$ を 加え $20 \mathrm{~min}$ 攪找後, $45^{\circ} \mathrm{C}$ 以下で減圧下に濃縮 (ca. $100 \mathrm{ml})$ し, これを冷水 $(800 \mathrm{ml})$ に注ぐ。析出する結 晶を吸引ろ取し, 水洗, 乾燥し $1,2: 3,4: 5,6$-tri$O$-isopropylidene-D-mannitol (27)27g(81\%), mp 67 $-69^{\circ} \mathrm{C}$ ，を得る。ついで(27) $30.2 \mathrm{~g}(0.1 \mathrm{~mol})$ を $70 \%$ 酢酸 $(500 \mathrm{ml})$ に溶解し $45^{\circ} \mathrm{C}$ で $1.5 \mathrm{~h}$ 攪拌する。減圧 下 $45^{\circ} \mathrm{C}$ 以下で溶媒を留去し, さらに benzene を加 え共沸によって残留する水を除く。残查に acetone を加え, 不溶物をろ別後, 濃縮し, benzene から再 結晶し monoacetonide(28)16.6g(74.8\%)，を得る： $\operatorname{mp~} 82-84^{\circ} \mathrm{C}$ 。

\section{3. キラルビルディングブロックの合成}

3.1. 1,2-O-Isopropylidene-(S)-glycerol( 2 )の合成 （a：*Scheme 1 の中のアルファベットに対応する。以 下同様）最も基本的なビルディングブロックである 1,2-O-isopropylidene- $(S)$-glycerol( 2 )はジアセトニド (26) から 1,2-O - isopropylidene - $(R)$ - glyceraldehyde （29）を経て得られる。この際, 不安定な水溶性の高い中

(a) (26)

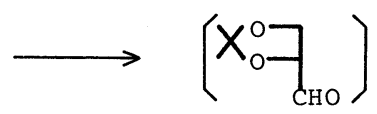

(29)

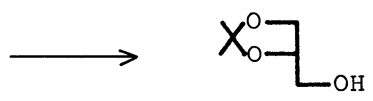

(2)
間体(29)は単離せず同一反応水溶液中でそのまま還元す る9)。得られる成績体( 2 ) は微量の不純物の混在のため ラセミ化するので長期の保存は好ましくない(スキーム 3 )。

1,2-O-Isopropylidene-(S)-glycerol ${ }^{9)}(2)$ 前記 diacetonide (26) $34.0 \mathrm{~g}(0.13 \mathrm{~mol})$ を $\mathrm{CH}_{2} \mathrm{Cl}_{2}(150 \mathrm{ml})$ に 溶解 し, $5 \%$ aq. $\mathrm{NaHCO}_{3}(60 \mathrm{ml})$ と水冷攪拌下に $\mathrm{NaIO}_{4} 30.6 \mathrm{~g}(0.143 \mathrm{~mol})$ の水溶液 $(90 \mathrm{ml})$ を滴下す る。同温で $1 \mathrm{~h}$ 攪汼, $\mathrm{NaBH}_{4} 4.93 \mathrm{~g}(0.13 \mathrm{~mol})$ を $10^{\circ} \mathrm{C}$ 以下で少量づつ加える。反応終了後, acetone を加 え過利の $\mathrm{NaBH}_{4}$ を分解後, 不溶物をセライトろ別 する。有機層を分取後水層を $\mathrm{CH}_{2} \mathrm{Cl}_{2}$ 抽出し, 合わ せた有機層を brine で洗い乾燥 $\left(\mathrm{K}_{2} \mathrm{CO}_{3}\right)$ する。溶媒 留去後, 減圧蒸留しアルコール ( 2 ) $27.4 \mathrm{~g}(80 \%)$ を 得 3 : bp $84^{\circ} \mathrm{C}(16$ torr $) ;[\alpha]_{\mathrm{D}}+11.4^{\circ}$ (c 5.29 , $\mathrm{MeOH})$ 。

3. 2. Ethyl 4,5-O-isopropylidene-(S) -4,5-dihydroxy-2-pentenoate ( 4 )の合成 (b) この $\delta$ 位にキラ ル中心を持つ機能性の高い $\alpha, \beta$-不飽和エステル $(4)$ は ビルディングブロックとして高い潜在価值を持つが, 不 安定なアルデヒド体(29)に対するWittig 反応によらな ければならず大量合成は困難であった ${ }^{10)}$ 。そこで 29 を 単離せず，生成と同時に同一反応水溶液中で炭酸カリウ ムの存在下にホスホン酸エステルによってこれを捕捉し 好収率で不飾和エステル体 (4)を得る手法を確立した 11)。従来の無水溶媒中強塩基を用いる場合と異なり $E-$ エステル (4)を優先し, $Z$-エステル $(30)$ の生成は $1 / 30$ 以下となる $($ スキーム 4$)$ 。

(b)

$(\underline{26})$

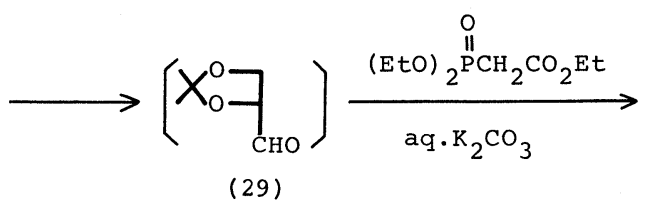

(29)
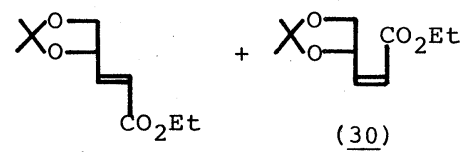

(4)

\section{Scheme 4}

上述のグリセロール誘導体( 2 )の場合と同様に，この 間の変換においては水溶性の高い中間体 $(29)$ の単離を要 せず, 反応を水溶液中で行うことができるので，無水溶 媒中で毒性の高い四酢酸鉛を用いなければならない従来 
の手法に較べ，安全性の点から好ましいと思われる。

Ethyl 4,5-O-isopropylidene-(S)-4,5-dihydroxy2-pentenoate ${ }^{11)}(4)$ 上記 diacetonide (26) $10.0 \mathrm{~g}$ $(38 \mathrm{mmol})$ を $5 \%$ aq. $\mathrm{NaHCO}_{3}(100 \mathrm{ml})$ 中に懸濁し, $0^{\circ} \mathrm{C}$ 攪拌下に $\mathrm{NaIO}_{4} 9.8 \mathrm{~g}(46 \mathrm{mmol})$ の水溶液 $(30 \mathrm{ml})$ を滴 下する。室温で $1 \mathrm{~h}$ 攪拌後, $0^{\circ} \mathrm{C}$ に冷却し, ethyl diethoxyphosphinylacetate $16.7 \mathrm{ml}(84 \mathrm{mmol})$, ついで $6 M$ aq. $\mathrm{K}_{2} \mathrm{CO}_{3}(130 \mathrm{ml})$ を加える。室温で $20 \mathrm{~h}$ 攪挥 後, $\mathrm{CH}_{2} \mathrm{Cl}_{2}$ で抽出し, 抽出層を水洗, 乾燥 $\left(\mathrm{K}_{2} \mathrm{CO}_{3}\right)$ する。溶媒を減圧で留去後, シリカゲルカ ラムクロマトグラフィーに付し成績体( 4 ) 13.14g (86\%) を得る。本品は $E / Z=97: 3$ の混合物であ る。両者はシリカゲルカラムクロマトグラフィーに よって分離出来る：E-isomer $(4): \mathrm{bp} 100-110^{\circ} \mathrm{C}$ (13torr) ; $[\alpha]_{\mathrm{D}}{ }^{17}+43.3^{\circ}\left(\mathrm{c} 0.5, \mathrm{CHCl}_{3}\right) \circ Z$-isomer (30) : bp $80-90^{\circ} \mathrm{C}$ (13torr); $[\alpha]_{\mathrm{D}^{17}}+124.3^{\circ}$ (c $\left.0.534, \mathrm{CHCl}_{3}\right)_{\circ}$

3. 3. (2R, 3R) -2,3-O-Isopropylidenethreitol ( 5 ) の 合成 (c) キラルな threitol 誘導体は酒石酸からも得 ることが出来るが，より高価な非天然型酒石酸に由来す る $(2 R, 3 R)$ 体 ( 5 )を D-マンニトール (1) から合成し た。即ちトリアセトニド(27)を同一水溶液中で部分脱ア セトニド化, グリコール開裂およびナトリウムボロヒド リドによる還元を行い $(2 R, 3 R)$-体 $(5)$ を得た ${ }^{12)}$ 。一 方, 還元剤に換えてホスホン酸エステルを同一反応水溶 液で反応させると $\mathrm{C}_{2}$-対称性を持つ bis- $\alpha, \beta-(E)$-不飽 和エステル体( 6 )が得られる ${ }^{13)}($ スキーム 5 )。

(c) and (d)
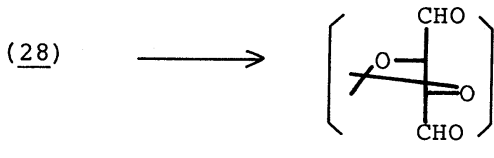

(31)
\ $(2 R, 3 R)-2,3-0$-Isopropylidenethreitol ${ }^{12)}$ ( 5) : 上記 triacetonide $(27) 20.1 \mathrm{~g}(66.5 \mathrm{mmol})$ を $70 \% \mathrm{AcOH}$ $(400 \mathrm{ml})$ に溶解し $40^{\circ} \mathrm{C}$ で $2 \mathrm{~h}$ 攪拌する。減圧下同温 で濃縮後, 残査を $20 \% \mathrm{aq} . \mathrm{K}_{2} \mathrm{CO}_{3}(60 \mathrm{ml})$ に溶解し, ついで $0^{\circ} \mathrm{C}$ で攪找下に $\mathrm{NaIO}_{4} 5.60 \mathrm{~g}(148 \mathrm{mmol})$ の水 溶液 $(60 \mathrm{ml})$ を加え, さらに $\mathrm{NaBH}_{4} 5.60 \mathrm{~g}(148 \mathrm{mmol})$ を少量ずつ加える。反応混合物に $\mathrm{CH}_{2} \mathrm{Cl}_{2}$ ( ca. $100 \mathrm{ml}$ )を加え, セライトろ過後, 有機層を除く(目 的物は水層に残る)。水層を減圧濃縮し, 残査を $\mathrm{CH}_{2} \mathrm{Cl}_{2}(5 \times 300 \mathrm{ml})$ で抽出し, 乾燥 $\left(\mathrm{MgSO}_{4}\right)$ する。 溶媒を留去後, 減压蒸留し $(2 R, 3 R)$-threitol 体 ( 5 ) $6.31 \mathrm{~g}(58.5 \%$ overall $)$ を得る : bp $133^{\circ} \mathrm{C}$ (0.22torr) ; $[\alpha]_{\mathrm{D}}{ }^{27}-3.58^{\circ}\left(\mathrm{c} 5.19, \mathrm{CHCl}_{3}\right)$ 。

Diethyl $(4 R, 5 R)$-O-isopropylidene-4,5-dihydroxy-2, 6-octadiene-1, 8-dicarboxylate ${ }^{13)}(6)$ 上 記(28) $2.82 \mathrm{~g}(1.27 \mathrm{mmol})$ を $5 \%$ aq. $\mathrm{NaHCO}_{3}(25 \mathrm{ml})$ に 溶解し, $0^{\circ} \mathrm{C}$ で攪拌下に $\mathrm{NaIO}_{4} 8.15 \mathrm{~g}(38 \mathrm{mmol})$ の水 溶液 $(25 \mathrm{ml})$ を滴下し, 室温でさらに $1 \mathrm{~h}$ 攪拌する。 再び $0^{\circ} \mathrm{C}$ に冷却し; ethyl diethoxyphosphinylacetate $10.1 \mathrm{ml}(50.8 \mathrm{mmol})$, さらに $10 \mathrm{M}$ aq. $\mathrm{K}_{2} \mathrm{CO}_{3}(50 \mathrm{ml})$ を加え, 室温で $16 \mathrm{~h}$ 攪拌する。 $\mathrm{CH}_{2} \mathrm{Cl}_{2}$ で抽出し, 有機層を brine で洗浄し, 乾燥 $\left(\mathrm{K}_{2} \mathrm{CO}_{3}\right)$ する。減圧 で溶媒留去し, 残査をシリカゲルカラムクロマトグ ラフィーに付し bis $(E)$ - ester ( 6 ) 2.36g (62\% overall)を得る：bp $135-140^{\circ} \mathrm{C}(0.2$ torr $) ;[\alpha]_{\mathrm{D}}{ }^{26}+$ $67.61^{\circ}\left(\mathrm{c} 1.15, \mathrm{CHCl}_{3}\right)$ 。

3.4.（R)-および(S)-1-O-Benzylglycerol（3)の合、
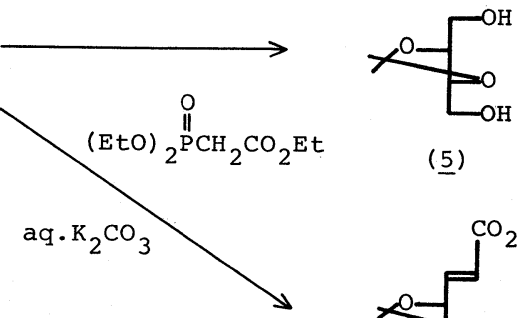

(ㅁ)

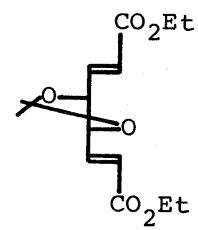

(ㅁ)

\section{Scheme 5}

$\checkmark$ 成 $((\mathrm{e})$ and $(\mathrm{f})) \quad$ ラミミ化し易いアルコール $(2)$ は直 ちにベンジル化つづく脱ケタール化によって $(R)-1-O-$ benzylglycerol ( 3 ) とする (33)に変換後, 無水酢酸中 2 モル当量の酢酸カリウムと 加熱すると選択的な反転が起こり好収率で diacetate 体
（34）を生成し，つづく脱アシル化で $(S)$-対掌体(3)が 得られる14)。これにより $\mathrm{D}$-mannitol( 1 )の使用に伴う両 対掌体の入手性という問題点が解決された(スキーム $6)$ 。

(R) -1-Benzylglycerol9) (3) 上記アセトニド体 
(e) and (f)

(2)

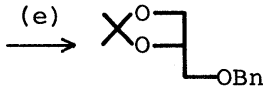

(32)
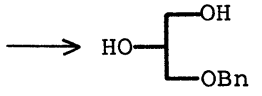

$(\mathrm{R})-(\underline{3})$

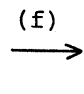

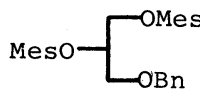

(33)

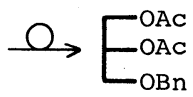

(34)

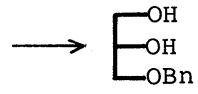

$(\mathrm{S})-(\underline{3})$
Scheme 6

( 2 ) $20 \mathrm{~g}(0.152 \mathrm{~mol})$ を $50 \%$ aq. $\mathrm{NaOH}(100 \mathrm{ml})$, benzyl bromide $32.4 \mathrm{ml}(0.272 \mathrm{~mol})$, benzyltriethylammonium chloride $(0.93 \mathrm{~g})$ と共に $100^{\circ} \mathrm{C}$ で $12 \mathrm{~h}$ 㩭拌す る。冷後水で希釈し $\mathrm{Et}_{2} \mathrm{O}$ 抽出する。抽出液を brine で洗浄し, 乾燥 $\left(\mathrm{Na}_{2} \mathrm{SO}_{4}\right)$ 後, 溶媒留去し, 残 查を $1.5 \mathrm{~N} \mathrm{H}_{2} \mathrm{SO}_{4}(120 \mathrm{ml})$ と $5 \mathrm{~h}$ 加熱する。冷後, $\mathrm{Et}_{2} \mathrm{O}$ 抽出し, 抽出層を $5 \%$ aq. $\mathrm{NaHCO}_{3}$ で洗浄, 乾 燥 $\left(\mathrm{Na}_{2} \mathrm{SO}_{4}\right)$ する。溶媒を留去し残査を隇圧蒸留に 付し $(R)$-diol 体 ( 3 )，21.3g(77.2\% overall)を得る : bp $110-120^{\circ} \mathrm{C}(0.15$ torr $) ;[\alpha]_{\mathrm{D}}+3.71^{\circ}$ (c 19.9 , $\left.\mathrm{CHCl}_{3}\right)_{\text {。 }}$

(S) -1-Benzylglycerol'14) (3) 上記 $(R)$ - Benzylglycerol ( 3 ) $1.30 \mathrm{~g}(7.14 \mathrm{mmol})$ を pyridine $(2.88 \mathrm{ml})$ を 含む $\mathrm{CH}_{2} \mathrm{Cl}_{2}(20 \mathrm{ml})$ 中 $\mathrm{MesCl}(2.04 \mathrm{~g}, 17.85 \mathrm{mmol})$ を

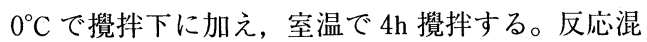
合液に水水 $(25 \mathrm{ml})$ を加え, $\mathrm{CH}_{2} \mathrm{Cl}_{2}$ で抽出し, 抽出 層を brine, $5 \% \mathrm{HCl}, 5 \%$ aq. $\mathrm{NaHCO}_{3}$, brine の順で 洗浄し, 乾燥 $\left(\mathrm{Na}_{2} \mathrm{SO}_{4}\right)$ する。溶媒留去し, 得られ る dimesylate $(33)(1,66 \mathrm{~g})$ を無水酢酸 $(25 \mathrm{ml})$ 中酢酸 カリウム $(2.45 \mathrm{~g}, 25 \mathrm{mmol})$ と $1.5 \mathrm{~h}$ 加熱還流する。 減圧で溶媒留去し, 残査を $\mathrm{CH}_{2} \mathrm{Cl}_{2}$ で抽出し, 抽出 層を brine, $5 \%$ aq. $\mathrm{NaHCO}_{3}$, brine の順で洗浄し, 乾燥 $\left(\mathrm{Na}_{2} \mathrm{SO}_{4}\right)$ ᄂ, 溶媒留去後減圧蒸留し $(S)$ - diacetate 体 (34) $1.31 \mathrm{~g}(91 \%)$ を得る：bp $135-145^{\circ} \mathrm{C}$ (0.17torr) ; $[\alpha]_{\mathrm{D}}-16.37^{\circ}\left(\mathrm{c} 4.56, \mathrm{CH}_{3} \mathrm{OH}\right) 。 \supset w$ で(34) $2.66 \mathrm{~g}(10 \mathrm{mmol})$ を $\mathrm{MeOH}(50 \mathrm{ml})$ 中 $\mathrm{K}_{2} \mathrm{CO}_{3} 3.04 \mathrm{~g}$ $(22 \mathrm{mmol})$ と室温下に $0.5 \mathrm{~h}$ 攪拌し, 減圧下に溶媒を 留去し, 残查を水で希釈し $\mathrm{CH}_{2} \mathrm{Cl}_{2}$ で抽出する。抽 出層を brine で洗浄, 乾燥 $\left(\mathrm{Na}_{2} \mathrm{SO}_{4}\right)$ L, 溶媒留去 後, 減圧蒸留し $(S)$-体 ( 3 ) 1.66g $(91 \%)$ を得る：bp $110-120^{\circ} \mathrm{C}(0.15$ torr $) ;[\alpha]_{\mathrm{D}}+3.71^{\circ}$ (c 19.9, $\left.\mathrm{CHCl}_{3}\right)_{\circ}$

3.5. (S) -1-O-Octadecylglycerol (7) の合成 (g) グリセロールの 1 級水酸基の選択的エーテル化に関連し て一般的に適用出来る結果を得たので 1 例を挙げる。す
でにアセタールあるいはケタール結合がジイソブチルア ルミニウムヒドリドによって還元的に開裂され対応する アルコキシエーテルを与えることを見出していたが15), この際水酸基が存在するとそれに近接する位置で選択的

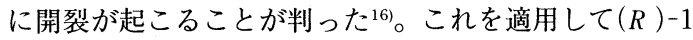
-benzylglycerol ( 3 )から血小板活性因子の鍵中間体であ る $(S)$-1-O-octadecylglycerol( 7 )の合成を行った ${ }^{17)}($ ス キーム 7$)$ 。

(g)
$(\mathrm{R})-(\underline{3})$

Scheme 7

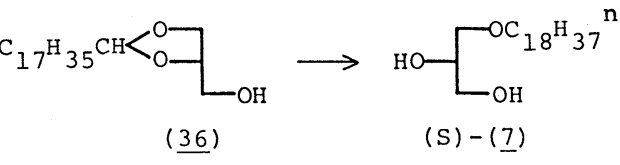

(S) -1-O-Octadecylglycerol ${ }^{77}(7)$ 上記 $(R)$ ( 3 ) $3.82 \mathrm{~g}(21 \mathrm{mmol})$ と stearylaldehyde $5.36 \mathrm{~g}(20 \mathrm{mmol})$ の $\mathrm{CH}_{2} \mathrm{Cl}_{2}$ 溶液 (80ml) を $p$ - TsOH76mg $(0.4 \mathrm{mmol})$ と $\mathrm{MgSO}_{4} 2.40 \mathrm{~g}(20 \mathrm{mmol})$ 存在下に室温で $24 \mathrm{~h}$ 攪拌す る。万過後有機層を水, $5 \%$ aq. $\mathrm{NaHCO}_{3}$, 水の順で 洗浄し, 乾燥 $\left(\mathrm{MgSO}_{4}\right)$ する。溶媒留去後, シリカゲ ルカラムクロマトグラフィーに付しアセタール(35) $6.11 \mathrm{~g}(71 \%)$ を得る。これ (35) $432 \mathrm{mg}(1.0 \mathrm{mmol})$ を $\mathrm{EtOH}(4 \mathrm{ml})$ に溶解し $10 \% \mathrm{Pd}-\mathrm{C}(100 \mathrm{mg})$ 存在下に $50^{\circ} \mathrm{C}$, 常圧で水素化 $(24 \mathrm{~h})$ ᄂ, 万過後, 溶媒留去す るとアルコール体(36)360mg(100\%)を得る。ついで (36) $278 \mathrm{mg}(0.81 \mathrm{mmol})$ の benzene $(2 \mathrm{ml})$ 溶液に氷冷 攪拌下に diisobutylaluminum hydride $(1.5 \mathrm{M}$ in toluene $) 2.7 \mathrm{ml}(4.1 \mathrm{mmol})$ を加え, 室温で $24 \mathrm{~h}$ 攪拌す る。反応物に $\mathrm{MeOH}(0.5 \mathrm{ml})$ および $15 \%$ aq. $\mathrm{NaOH}$ $(5 \mathrm{ml})$ を加え, $\mathrm{Et}_{2} \mathrm{O}$ で抽出する。抽出層を brine で洗浄し, 乾燥 $\left(\mathrm{MgSO}_{4}\right)$ 後, 溶媒留去し残査を pet. etherより再結晶しエーテル体 ( 7 ) $238 \mathrm{mg}$ ( $85 \%$ )を得 る: $\mathrm{mp} 70-71^{\circ} \mathrm{C} ;[\alpha]_{\mathrm{D}}-2.49^{\circ}$ (c 2.654, THF)。

3.6. (S) - O-Benzylglycidol ( 8 ) (h) キラル $O$ benzylglycidol ( 8 )はそのアルキル化能からこの種のキ ラルビルディングブロック中最大の機能性を持つ化合物 の 1 つである1”。1 級水酸基のモノトシル化を経る従来 法は選択性が完全ではなく9.18), 多量の副生物の生成が 大量合成を妨げていたが，ベンジリデンアセタール体 （37）に対するN-ブロモコハク酸イミドによる酸化的開 裂反応 ${ }^{19)}$ を適用することによってこれを解決した ${ }^{201}($ ス キーム 8 )。 
(h)

$(R)-(\underline{3})$
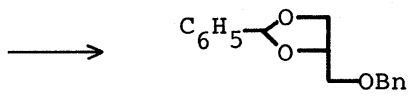

(37)

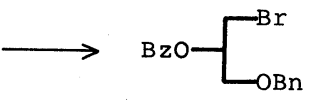

$(\underline{38)}$
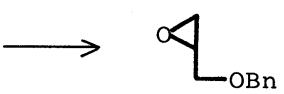

()ㅜ)

\section{Scheme 8}

(S)-O-Benzylglycidol ( 8 ) 上記 $(R)-(3) 18.2 \mathrm{~g}$ $(100 \mathrm{mmol})$ と benzaldehyde $10.6 \mathrm{~g}(100 \mathrm{mmol})$ を benzene $(200 \mathrm{ml})$ 中 $p-\mathrm{TsOH}(100 \mathrm{mg})$ の存在下に DeanStark 装置を付して $5 \mathrm{~h}$ 還流する。冷後, 反応液を $5 \%$ aq. $\mathrm{NaHCO}_{3}$, brine で洗浄 $L$, 乾燥 $\left(\mathrm{Na}_{2} \mathrm{SO}_{4}\right)$ 後, 減圧で溶媒留去し benzylidene acetal(37)28.6g $(100 \%)$ を得る。これを $\mathrm{CCl}_{4}(200 \mathrm{ml})$ 中 NBS $(19.8 \mathrm{~g}, 111 \mathrm{mmol})$ と遮光下に $26 \mathrm{~h}$ 攪拌後, 沈殿物 をろ別し， ろ液を $5 \%$ aq. $\mathrm{NaHCO}_{3}$, brine で洗浄 し, 乾燥 $\left(\mathrm{Na}_{2} \mathrm{SO}_{4}\right)$ し, 溶媒留去し臭化エステル体 (38) $34.9 \mathrm{~g}$ を得る。この (38) $25.5 \mathrm{~g}$ (73mmol) を dimethoxyethane $(300 \mathrm{ml})$ に溶かしこれに粉末 $\mathrm{NaOH7.3g}(182 \mathrm{mmol})$ を眯濁させ室温下に $24 \mathrm{~h}$ 攪拌 する。混合物に sat. aq. $\mathrm{NaOH}(100 \mathrm{ml})$ を注ぎ, $\mathrm{Et}_{2} \mathrm{O}$ で抽出する。抽出層を $5 \%$ aq. $\mathrm{NaHCO}_{3}$, brine で洗 浄 L, 乾燥 $\left(\mathrm{Na}_{2} \mathrm{SO}_{4}\right)$ し, 溶媒留去後, 減圧蒸留 L, (S )-O-Benzylglycidol ( 8 )8.50g (71\% overall) を得る： bp $120^{\circ} \mathrm{C}(0.22$ torr $) ;[\alpha]_{\mathrm{D}}-15.25^{\circ}$ (neat)。

3.7. (S) -5-Hydroxy-4-pentanolide ( 9 ) および (S)5-Hydroxy-2-penten-4-olide (10)の合成 ((i) および (j)) 多様の対象物の構築に適用出来る極めて有用な 2 種の 5
員環ラクトン $(9)$ および(10)を上記の不飽和エステル (4)から簡便に得た ${ }^{11)}$ 。従来, これらは $\mathrm{L}^{-ク ゙ ル タ ミ ン ~}$ 酸 ${ }^{21,22)}$ ，やリボノラクトン23.24)などの天然物からあるい は Sharpless 酸化を経て ${ }^{25)}$ 得られていたが本法ははるか に効率的に両者を与えることが出来る(スキーム 9$)$ 。

(S) -5-Hydroxy-4-pentanolide ${ }^{11)}$ ( 9) 前記 (4) $815 \mathrm{mg}(4.07 \mathrm{mmol})$ を $\mathrm{EtOH}(15 \mathrm{ml})$ 中 $10 \% \mathrm{Pd}-\mathrm{C}$ $(45 \mathrm{mg})$ の存在下に $10 \mathrm{~h}$ 水素化する。万過後溶媒留 去し飽和エステル体 $(39), 778 \mathrm{mg}(95 \%)$ を得る; bp $100-110^{\circ} \mathrm{C}(13$ torr $) ;[\alpha]_{\mathrm{D}}{ }^{18}-4.75^{\circ}(\mathrm{c} 2.02, \mathrm{MeOH})$ 。 ついで(39) $230 \mathrm{~m}(1.15 \mathrm{mmol})$ を $\mathrm{CF}_{3} \mathrm{CO}_{2} \mathrm{H}(0.1 \mathrm{ml})$ を 含む $50 \%$ aq. THF $(1 \mathrm{ml})$ に溶かし室温で $1 \mathrm{~h}$ 攪拌す る。室温で水流ポンプ減圧下に大部分の溶媒を留去 し，そのまま減圧蒸留するとラクトン体( 9 ) $117 \mathrm{mg}$ (88\%) を得る：bp $110-115^{\circ} \mathrm{C}(0.2$ torr $) ;[\alpha]_{\mathrm{D}}{ }^{27}+$ $32.7^{\circ}$ (c 3.04 , EtOH)。

(S) -5-Hydroxy-4-pentenolide ${ }^{11)}$ (10) 前記 ( 4) $5.0 \mathrm{~g}(25 \mathrm{mmol})$, thiophenol $5.5 \mathrm{~g}(42.5 \mathrm{mmol})$, およ び ethyldiisopropylamine $(98 \% 6.46 \mathrm{~g}, 50 \mathrm{mmol})$ を benzene $(50 \mathrm{ml})$ 中で室温下に $42 \mathrm{~h}$ 攪拌する。溶媒留 去後, シリカゲルカラムクロマトグラフィーで精製 し 2 種のエピマー混合物 $(57: 43)$ として sulfide (41) $7.8 \mathrm{~g}(100 \%)$ を得る。(41) $348 \mathrm{mg}(1.12 \mathrm{mmol})$ を conc. $\mathrm{HCl}(0.5 \mathrm{ml})$ を含む $\mathrm{EtOH}(5 \mathrm{ml})$ 中で室温下 $22 \mathrm{~h}$ 攪拌し, 減圧でエタノールを留去後, $\mathrm{CH}_{2} \mathrm{Cl}_{2}$ で抽出する。抽出層を $5 \%$ aq. $\mathrm{NaHCO}_{3}$ と brine で洗 浄し, 乾燥 $\left(\mathrm{Na}_{2} \mathrm{SO}_{4}\right)$ 後, 溶媒留去しラクトン体 (42) $257 \mathrm{mg}($ 100\%) を得る。ついで (42) $538 \mathrm{mg}$ $(2.4 \mathrm{mmol})$ を $30 \%$ aq. $\mathrm{H}_{2} \mathrm{O}_{2} 0.68 \mathrm{ml}(6.0 \mathrm{mmol})$ を含 む酢酸 $(5 \mathrm{ml})$ 中で室温下に $2 \mathrm{~h}$ 攪找後, 反応液を brine で希釈し $\mathrm{CH}_{2} \mathrm{Cl}_{2}$ で抽出する。抽出層を $5 \%$ aq. $\mathrm{NaHCO}_{3}$, brine で洗浄し, 乾燥 $\left(\mathrm{Na}_{2} \mathrm{SO}_{4}\right)$ し, 溶

(i) and (j)

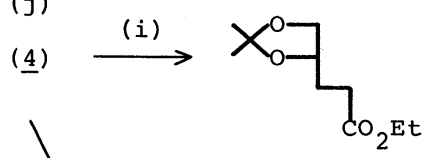

(39)

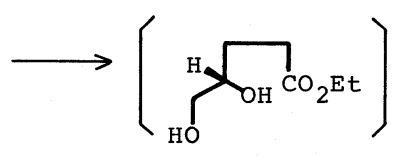

$(\underline{40)}$

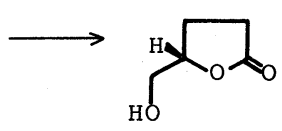

(9)

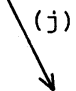

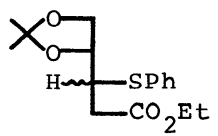

(41)

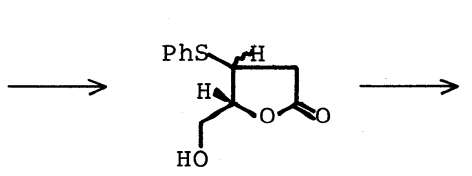

(42)

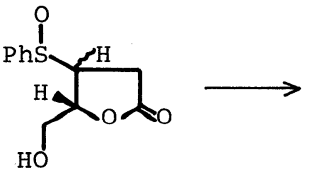

(43)<smiles>O=C1C=C[C@@H](CO)O1</smiles>

(10)

Scheme 9 
媒留去し粗 sulfoxide 体(43)466mg (81\%)を得，これ を直ちに toluene $(5.0 \mathrm{ml})$ 中 $\mathrm{CaCO}_{3} 720 \mathrm{mg}(7.2 \mathrm{mmol})$ と $3 \mathrm{~h}$ 還流する。ろ過後, 濃縮し, シリカゲルカラ ムクロマトグラフィーに付すと butenolide (10) $189 \mathrm{mg}(69 \%$ overall $)$ を得る：bp $130^{\circ} \mathrm{C}(0.9$ torr $)$; $\mathrm{mp} 39-40^{\circ} \mathrm{C}\left(\mathrm{CHCl}_{3}-\mathrm{Et}_{2} \mathrm{O}\right) ;[\alpha]_{\mathrm{D}}{ }^{24}-136.3^{\circ}$ ( с 0.25 , $\left.\mathrm{H}_{2} \mathrm{O}\right)_{\circ}$

(k)

(4)

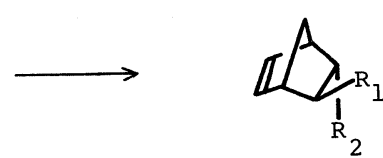

$(\underline{44})$

(a) $\mathrm{R}_{1}=\mathrm{CO}_{2} \mathrm{Et}, \mathrm{R}_{2}=\mathrm{J}^{\mathrm{O}}$

(b) $\mathrm{R}_{1}=T_{\mathrm{O}_{X} \mathrm{O}}, \mathrm{R}_{2}=\mathrm{CO}_{2} \mathrm{Et}$

(모)

(a) $\mathrm{R}_{1}=\mathrm{CH}_{2} \mathrm{OH}, \mathrm{R}_{2}={ }^{1} \mathrm{O}$

(b) $\mathrm{R}_{1}=\mathrm{T}^{\prime} \mathrm{O}, \mathrm{R}_{2}=\mathrm{CH}_{2} \mathrm{OH}$
3.8. $(2 R, 3 R)-2,3-D i h y d r o x y m e t h y 1-5-n o r b o r n e n e$ (11)の含成 (k) 前記不飽和エステル $(4)$ からビルデ イングブロックとして利用価值の高い 2,3 -ジ置換 norbornene 誘導体 $(2 R, 3 R)$ - (11)を cyclopentadiene との Diels-Alder 反応によって得た ${ }^{27)}$ 。付加に際して endo lexo 比は低かったが面選択性は高く，そこで両置換基を 同一官能基に変換することにより単一のジオール体 $(2 R, \downarrow$

\section{Scheme 10}

$\checkmark 3 R)-(11)$ に誘導した $($ スキーム10)。

$(2 R, 3 R)-2,3$-Dihydroxymethyl-5-norbornene ${ }^{27 b)}$

(11) 上記 ( 4$) 1.0 \mathrm{~g}(5.0 \mathrm{mmol})$ の $\mathrm{CH}_{2} \mathrm{Cl}_{2}(10 \mathrm{ml})$ 溶 液に $-20^{\circ} \mathrm{C}$ で覺汼下に diethylaluminum chloride (1M in hexane) $5.5 \mathrm{ml}(5.5 \mathrm{mmol})$ を滴下し, $30 \mathrm{~min}$ 後, cyclopentadiene $2.07 \mathrm{ml}(25 \mathrm{mmol})$ を一挙に加え 同温で $12 \mathrm{~h}$ 攪拌する。反応混合物に $\mathrm{Na}_{2} \mathrm{CO}_{3}$. $10 \mathrm{H}_{2} \mathrm{O}(5.72 \mathrm{~g}, 20 \mathrm{mmol})$ を少量づつ加えさらに $5 \mathrm{~h}$ 攪拌してからセライトろ過し, ろ液を brine で洗浄 し, 乾燥 $\left(\mathrm{Na}_{2} \mathrm{SO}_{4}\right)$ する。溶媒留去後シリカゲルカ ラムクロマトグラフィーに付し endo/exo $(3: 1)$-混 合物 (44a, b) 1.24g (93\%) を得る。この混合物 $4.08 \mathrm{~g}(15.3 \mathrm{mmol})$ の $\mathrm{THF}(10 \mathrm{ml})$ 溶液を $0^{\circ} \mathrm{C}$ 攪找下に
$\mathrm{LiAlH}_{4} 639 \mathrm{mg}(16.9 \mathrm{mmol})$ の THF $(30 \mathrm{ml})$ 懸濁液に滴 下し，同温で $20 \mathrm{~min}$ 攪拌する。混合物に $30 \%$ $\mathrm{NH}_{4} \mathrm{OH}$ (ca. $10 \mathrm{ml}$ )を加え還元剤を分解後, セライト 万過 L, 万液を brine で洗浄 L, 乾燥 $\left(\mathrm{Na}_{2} \mathrm{SO}_{4}\right)$ し, 溶媒留去し endo/exo-アルコール混合物 (45a,

b) $3.3 \mathrm{~g}(96 \%)$ を得る。この混合物 $450 \mathrm{mg}$ (2.01 mmol)を $10 \% \mathrm{HCl}(1 \mathrm{ml})$ と $\mathrm{MeOH}(4 \mathrm{ml})$ の混液 中で $0^{\circ} \mathrm{C}$ で $30 \mathrm{~min}$ 攪拌し脱アセトニド化後, $5 \%$ aq. $\mathrm{NaHCO}_{3}$ を加えて塩基性としてから $\mathrm{NaIO}_{4} 516 \mathrm{mg}$ $(2.41 \mathrm{mmol})$ の水溶液 $(1 \mathrm{ml})$, ついで $\mathrm{NaBH}_{4} 164 \mathrm{mg}$ $(4.42 \mathrm{mmol})$ を同温で加え, $15 \mathrm{~min}$ 攪拌する。反応 混合物を $\mathrm{CH}_{2} \mathrm{Cl}_{2}$ で抽出し, 抽出層を brine で洗浄 し, 乾燥 $\left(\mathrm{Na}_{2} \mathrm{SO}_{4}\right)$ し, 溶媒留去後シリカゲルカラ
(1)

(6)

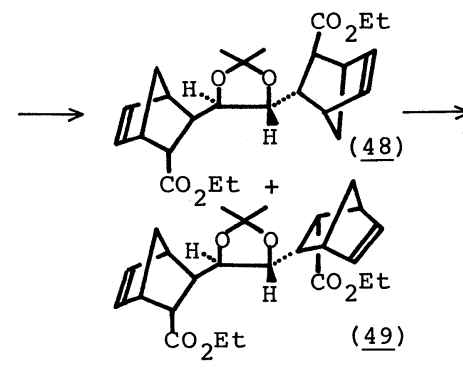

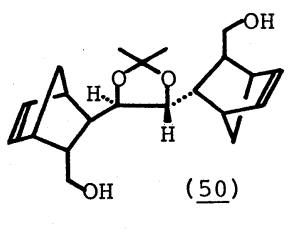

$\mathcal{C O H}_{\mathrm{OH}}$

$(S, S)-(\underline{11})$

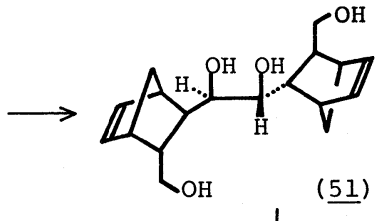

(51) 
ムクロマトグラフィーに付し $(2 R, 3 R)-\operatorname{diol}(11)$ $272 \mathrm{mg}(88 \%)$ を得る：bp $85-90^{\circ} \mathrm{C}(0.2$ torr $) ;[\alpha]_{\mathrm{D}}{ }^{27}$ $+23.06^{\circ}\left(\mathrm{c} 1.01, \mathrm{CHCl}_{3}\right)$ 。

\section{9. (2S, 3S) -2,3-Dihydroxymethyl-5-norbornene}

(11) の合成 (1) 本化合物は前記 $(2 R, 3 R)$-体(11) の対掌体であるが前記の手法によれば入手困難な $\mathrm{L}^{-}$ mannitol に由来する $(R)-\alpha, \beta$-不飽和エステル体 ( 4 ) に依存しなければならない。我々はbis-ester 体( 6 )の キラル背景が丁度, 前記 $(R)-\operatorname{ester}(4)$ のそれと同一で あることに着目し（６）に対するDiels-Alder 反応を行っ た。その結果, 完全な選択性は認められなかったが予期 した立体化学を持つ付加体(48)を主成分とする 2 種の付 加体が選択的に得られ, 再結晶によって望ましくない一 方 $(49)$ を除き目的とする $(2 S, 3 S)-\operatorname{diol}(11)$ のを得た27) (スキーム11)。

(2S, 3S) -2,3-Dihydroxymethyl-5-norbornene ${ }^{27 b)}$ (11) 上記 ( 6$) 6.0 \mathrm{~g}(20 \mathrm{mmol})$ の $\mathrm{CH}_{2} \mathrm{Cl}_{2}(60 \mathrm{ml})$ 溶液 に $-20^{\circ} \mathrm{C}$ で攪拌下に diethylaluminum chloride $(1 \mathrm{M}$ in hexane) $44 \mathrm{ml}(44 \mathrm{mmol})$, ついで cyclopentadiene $16.6 \mathrm{ml}(200 \mathrm{mmol})$ を一挙に加え同温で $20 \mathrm{~h}$ 保 つ, 混合物に $5 \%$ aq. $\mathrm{NaHCO}_{3}(20 \mathrm{ml})$ を加え室温で $5 \mathrm{~h}$ 攪拌後, $\mathrm{CH}_{2} \mathrm{Cl}_{2}$ を加えセライトろ過し，有機層を 分取する。有機層を brine で洗浄し, 乾燥 $\left(\mathrm{K}_{2} \mathrm{CO}_{3}\right)$ し, 溶媒留去し, シリカゲルカラムクロマトグラフ イーに付し,さらに pet. ether から再結晶すると $(2 S, 3 S ； 2$ 'S ,3'S ) - 付加体 (48) $5.53 \mathrm{~g}(64 \%)$ を得 る; mp $77-78^{\circ} \mathrm{C} ;[\alpha]_{\mathrm{D}}{ }^{24}+13.81^{\circ}\left(\mathrm{c} 1.00, \mathrm{CHCl}_{3}\right)$ 。 母液より $\left(2 S, 3 S ; 2 R, 3^{\prime} R\right)$-付加体 (49) $2.76 \mathrm{~g}$ $(32 \%)$ が得られる: $[\alpha]_{\mathrm{D}}{ }^{22}+15.17^{\circ}(\mathrm{c} 1.01$, $\left.\mathrm{CHCl}_{3}\right)$ 。ついで(48) $1.29 \mathrm{~g}(3.0 \mathrm{mmol})$ の $\mathrm{THF}(3 \mathrm{ml})$ 溶液を $0^{\circ} \mathrm{C}$ で攪找下に $\mathrm{LiAlH}_{4} 227 \mathrm{mg}(6.0 \mathrm{mmol})$ の $\mathrm{THF}(10 \mathrm{ml})$ 懸濁液中に滴下し, 同温で $20 \mathrm{~min}$ 攪拌 $(m),(n),(s),(t),(u)$, and $(v)$

(8)

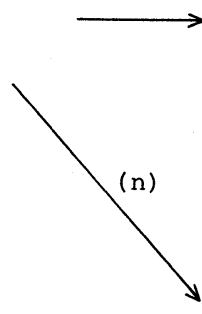

(m)

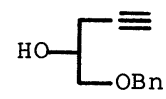

(t)
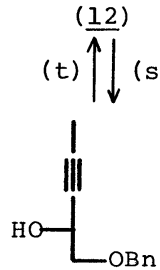

(13)
する。反応混合物に $30 \% \mathrm{NH}_{4} \mathrm{OH}(2 \mathrm{ml})$ を加え還元 片を分解後，七ライトろ過し，ろ液を brine で洗浄 し, 乾燥 $\left(\mathrm{MgSO}_{4}\right)$ し, 減圧で溶媒留去し bis-alcohol (50) 1.03g (99\%) を得る。ついで (50) 200mg $(0.56 \mathrm{mmol})$ を $10 \% \mathrm{H}_{2} \mathrm{SO}_{4}(1 \mathrm{ml})$ と $\mathrm{THF}(1 \mathrm{ml})$ の混 液中で $60^{\circ} \mathrm{C}$ で $3.5 \mathrm{~h}$ 加温し脱ケタール化し，5\%aq. $\mathrm{NaHCO}_{3}$ を加えてアルカリ性とした後, $0^{\circ} \mathrm{C} て ゙$ $\mathrm{NaIO}_{4} 239 \mathrm{mg}(1.12 \mathrm{mmol})$ の水溶液 $(1 \mathrm{ml})$, さらに $\mathrm{NaBH}_{4} 43 \mathrm{mg}$ (1.12mmol) を加え $15 \mathrm{~min}$ 攪拌を続け る。反応混合物を $\mathrm{CH}_{2} \mathrm{Cl}_{2}$ で抽出し, brine で洗浄 し, 乾燥 $\left(\mathrm{MgSO}_{4}\right)$ し, 溶媒留去後, 減圧蒸留すると (2S , 3S )- diol(11) $131 \mathrm{mg}(76 \%)$ を得る : bp $85-90^{\circ} \mathrm{C}$ $(0.2$ torr $):[\alpha]_{\mathrm{D}}{ }^{24}+24.9^{\circ}\left(\mathrm{c} 0.88, \mathrm{CHCl}_{3}\right)$ 。

3.10. $\mathrm{C}_{5}$-キラルビルディングブロック類の合成 $((\mathrm{m}),(\mathrm{n}),(\mathrm{r}),(\mathrm{s}),(\mathrm{t})$ および $(\mathrm{u}))$ 1-O-Benzylglycidol( 8 )とアセチレン単位の組合せによって多様 の機能性を持つ一連の 5 炭素キラルビルディングブロッ クを合成した。DMSO 中カリウム $t$ ーブトキシドによっ てキラリティーを損なうことなく末端アセチレン(12)が 内部アセチレン(13)に移動することを見出し，これによ り多様の変換に対応出来る $Z$-および $E$-オレフィン部 を持つアリルアルコール誘導体(18)拉よび(19)の容易な 合成が可能となった ${ }^{28)}($ スキーム12)。

(R) -5-Benzyloxy - 4-hydroxy - 1-pentyne ${ }^{28)}(12)$ 上記 $(S)-(8) 20.0 \mathrm{~g}(122 \mathrm{mmol})$ の $\mathrm{DMSO}(80 \mathrm{ml})$ 溶液 に攪拌下 $5^{\circ} \mathrm{C}$ 以下で lithium acetylide ethylenediamine complex (90\%)18.7g (183mmol)を少量づつ 加え, 同温で $40 \mathrm{~min}$ 攪拌する。反応混合物に brine (150ml)を加え，ついで conc. $\mathrm{HCl}$ を加え酸性とし $\mathrm{Et}_{2} \mathrm{O}$ で抽出する。抽出液を $5 \%$ aq. $\mathrm{NaHCO}_{3}$, brine で洗浄し, 乾燥 $\left(\mathrm{MgSO}_{4}\right)$ し, 溶媒留去後シリカゲル カラムクロマトグラフィーに付し末端 acetylene 体

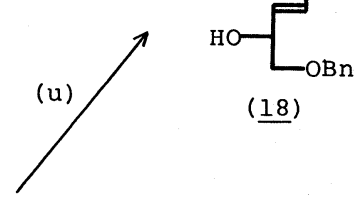

(v)

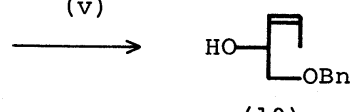


（12)20.69(89\%)を得る：bp $95^{\circ} \mathrm{C}(0.3$ torr $) ;[\alpha]_{\mathrm{D}}{ }^{21}$ $-12.0^{\circ}$ (c 2.14, $\mathrm{CHCl}_{3}$ )。

(R) -5-Benzyloxy-4-hydroxy-2-pentyne (13) from (8) ${ }^{28)}$ 上記 $(S)$ - ( 8 ) $500 \mathrm{mg}(3.05 \mathrm{mmol})$ の DMSO $(5 \mathrm{ml})$ 溶液に lithium acetylide ethylenediamine complex $(90 \%) 468 \mathrm{mg}(4.57 \mathrm{mmol})$ を氷冷擤拌下に加 え，さらに室温下に $12 \mathrm{~h}$ 攪找を続ける。ついで同 温で溶液中に $t$-BuOK684mg $(6.10 \mathrm{mmol})$ を加え, さ らに $2 \mathrm{~h}$ 㩭拌する。反応液中に $10 \% \mathrm{HCl}$ を加え酸性 とし $\mathrm{Et}_{2} \mathrm{O}$ で抽出し, 抽出層を $5 \%$ aq. $\mathrm{NaHCO}_{3}$, brine で洗浄し, 乾燥 $\left(\mathrm{MgSO}_{4}\right)$ する。溶媒留去後シ リカゲルカラムクロマトグラフィーに付し内部 acetylene 体 (13) $460 \mathrm{mg}(79.4 \%)$ を得る：bp $183^{\circ} \mathrm{C}$ (0.88torr); $[\alpha]_{\mathrm{D}}{ }^{28}-4.99^{\circ}\left(\mathrm{c} 1.00, \mathrm{CHCl}_{3}\right)$ 。

(R) -5-Benzyloxy-4-hydroxy-2-pentyne (13) from (12) ${ }^{28)} t$ - BuOK15.36g $(137 \mathrm{mmol})$ を溶かした DMSO (100ml) に室温，㩭拌下に上記 (12) $13.0 \mathrm{~g}$ $(68.4 \mathrm{mmol})$ を加え, $60 \mathrm{~min}$ 攪找を続ける。反応混 合物は上記同様処理すると内部 acetylene 体(13) $12.7 \mathrm{~g}(93 \%)$ を得る。

内部 acetylene 体 (13) から末端 acetylene 体 (12) への変換 ${ }^{28)}$ 1,3-Diaminopropane (13ml) 中に $\mathrm{KH} 695 \mathrm{mg}$ (17.3mmol) (35\% oil dispersion を hexane で洗浄)を懸濁させ $0^{\circ} \mathrm{C}$ 㩭汼下に上記(13)(一部 (12) も含む) $817 \mathrm{mg}(4.30 \mathrm{mmol})$ を加え, 室温で $8 \mathrm{~h}$ 攪拌 を続ける。反応混合物に brine $(10 \mathrm{ml})$ を加え，つい で $\mathrm{Et}_{2} \mathrm{O}$ で抽出する。抽出層を $10 \% \mathrm{HCl}, 5 \%$ aq. $\mathrm{NaHCO}_{3}$, brine で洗浄し, 乾燥 $\left(\mathrm{MgSO}_{4}\right)$ する。溶 媒留去後減圧蒸留し末端 acetylene 体 (12) $637 \mathrm{mg}$ (78\%) を得る：bp $95^{\circ} \mathrm{C}(0.3$ torr $)$ 。

\section{$(R)$ - $(E)$-1-Benzyloxy-2-hydroxy-3-pentene (18) ${ }^{28)}$}

$\mathrm{LiAlH}_{4} 310 \mathrm{mg}(7.93 \mathrm{mmol})$ を懸濁したTHF $(5 \mathrm{ml})$ に 上記(13) $754 \mathrm{mg}(3.97 \mathrm{mmol})$ を加え，攪拌下に $4 \mathrm{~h}$ 還 流する。冷後反応混合物に $30 \% \mathrm{NH}_{4} \mathrm{OH}$ を加えて過 剩の還元剂を分解後, $\mathrm{Et}_{2} \mathrm{O}$ を加え, セライトろ過 する。溶媒を留去後, 減圧蒸留し $(E)-\operatorname{alcohol}(18)$ $711 \mathrm{mg}(93 \%)$ を得る：bp $110^{\circ} \mathrm{C}(0.8$ torr $) ;[\alpha]_{\mathrm{D}}{ }^{29}-$ $15.69^{\circ}$ (c $\left.1.03, \mathrm{CHCl}_{3}\right)$ 。

\section{(R) - (Z) -1-Benzyloxy-2-hydroxy-3-pentene}

(19) ${ }^{28)}$ 上記 (13) $100 \mathrm{mg}(0.526 \mathrm{mmol})$ を $\mathrm{AcOEt}(1$ $\mathrm{ml})$ 中 Lindlar 触媒 $(10 \mathrm{mg})$ の存在下室温, 常圧下に 水素化する。1 モル当量の吸収 (1.5h) 後, 触媒をろ 別し，溶媒を留去し $(Z)$ - alcohol (19) $82 \mathrm{mg}(81 \%)$ を 得る：bp110 $\mathrm{C}(0.8$ torr $) ;[\alpha]_{\mathrm{D}}{ }^{30}-41.5^{\circ}$ (c 0.90 , $\left.\mathrm{CHCl}_{3}\right)_{\text {。 }}$
3.11. (S) -1-S-Phenyl-3-O-benzyl-1-thioglycerol (14) および (S) - (3E) -1-Benzyloxy-3, 5-hexadien-2ol (21) の合成 ( (w) and (x)) 上記 $(S)-(8)$ から sulfide(14)を経て得た sulfoxide 体(53)のアルキル化反応 とそれに続く位置抢よび立体選択的な syn 脱離によって allyl, cinnamyl, および $(E, E)-2,4$ - hexadienyl アル

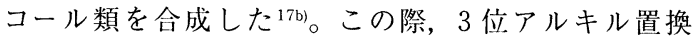
allyl アルコール類の形成に際しては立体選択性は 低い17b)(スキーム13)。

(o) and (x)

(ㅇ)

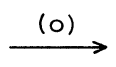

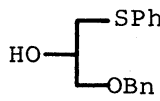

(14)

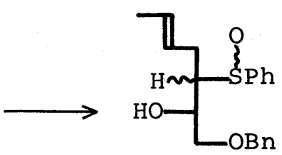

(54)
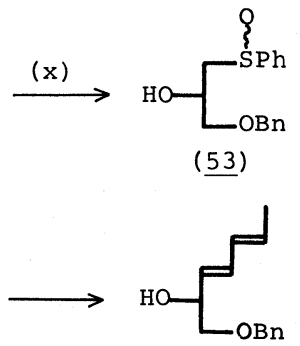

(21)

\section{Scheme 13}

(S) -1-S-Phenyl-3-O-benzyl-1-thioglycerol ${ }^{29}$

（14） $\mathrm{NaH} 1.39 \mathrm{~g}(69.2 \mathrm{mmol})$ の THF (80ml) 懸濁液 に氷冷，攪拌下に thiophenol $5.92 \mathrm{ml}(69.2 \mathrm{mmol})$ を 加え, 同温で $30 \mathrm{~min}$ 攪找後, 上記 $(S)-(8) 9.44 \mathrm{~g}$ $(57.7 \mathrm{mmol})$ の THF $(20 \mathrm{ml})$ 溶液を滴下し，さらに $20 \mathrm{~min}$ 攪找する。 $\mathrm{Et}_{2} \mathrm{O}(250 \mathrm{ml})$ で希釈し, $\mathrm{H}_{2} \mathrm{O}$ と brine で洗浄し, 乾燥 $\left(\mathrm{MgSO}_{4}\right)$ ᄂ, 溶媒留去後, シ リカゲルカラムクロマトグラフィーに付すと sulfide 体 (14) $14.14 \mathrm{~g}(89 \%)$ を得る：[ $\alpha]_{\mathrm{D}}-14.37^{\circ}(\mathrm{c}$ 4.176, $\left.\mathrm{CHCl}_{3}\right)$ 。

(S) - (3E) - 1-Benzyloxy-3, 5-heptadien-2-o $\mathrm{ol}^{30}$

(21) 上記 (14) $9.72 \mathrm{~g}(35.5 \mathrm{mmol})$ を $30 \% \mathrm{H}_{2} \mathrm{O}_{2} 6.03 \mathrm{ml}$ (53.3mmol)の $\mathrm{MeOH}(40 \mathrm{ml})$ 溶液に溶解し室温下 3 日間攪拌する。減圧で $\mathrm{MeOH}$ を留去後, $\mathrm{CH}_{2} \mathrm{Cl}_{2}$ (50m1)を加え，有機層を分取する。有機層を brine で洗浄し, 乾燥 $\left(\mathrm{MgSO}_{4}\right)$ L, 溶媒留去し sulfoxide 体 (53) 10.34g (100\%)を得る。この (53) 1.08g $(3.72 \mathrm{mmol})$ の $\mathrm{THF}(30 \mathrm{ml})$ 溶液に HMPA $1.43 \mathrm{ml}$ $(8.19 \mathrm{mmol})$ を加え， $-70^{\circ} \mathrm{C}$ ，攪拌下に $n \mathrm{BuLi}$ $(15 \% \mathrm{w} / \mathrm{w}$ in hexane $) 3.55 \mathrm{ml}(8.19 \mathrm{mmol})$ を加え, $30^{\circ} \mathrm{C}$ で $45 \mathrm{~min}$, 室温で $50 \mathrm{~min}$ 攪拌後, $-73^{\circ} \mathrm{C}$ と L, $(E)$ - crotyl bromide $0.42 \mathrm{ml}(4.10 \mathrm{mmol})$ を滴下 し，同温で $30 \mathrm{~min}$ 穓拌する。反応液に sat. aq. $\mathrm{NH}_{4} \mathrm{Cl}$ を加え減圧で溶媒を濃縮後 $\mathrm{CH}_{2} \mathrm{Cl}_{2}$ を加え, 有機層を分取し， $10 \% \mathrm{HCl} ， 5 \%$ aq. $\mathrm{NaHCO}_{3}$, brine 
で順次洗浄し, 乾燥 $\left(\mathrm{MgSO}_{4}\right)$ する。溶媒留去後残査 1.34g (100\%)をそのまま toluene $(40 \mathrm{ml})$ に溶解し $\mathrm{CaCO}_{3} 1.12 \mathrm{~g}(11.16 \mathrm{mmol})$ 存在下に $1 \mathrm{~h}$ 還流する。 $\mathrm{Et}_{2} \mathrm{O}$ を加えろ過し, $5 \%$ aq. $\mathrm{NaHCO}_{3}$, brine で洗浄 L, 乾燥 $\left(\mathrm{MgSO}_{4}\right)$ し, 溶媒留去後, シリカゲルカラ ムクロマトグラフィーに付すと $(E)$-diene 体 (21) $523 \mathrm{mg}(64 \%$ overall from 14$)$ を得る : $[\alpha]_{\mathrm{D}}-6.48^{\circ}(\mathrm{c}$ $\left.1.048, \mathrm{CHCl}_{3}\right)$ 。

3.12. $\alpha$-置換- $\gamma(\boldsymbol{R})$-Benzyloxymethyl- $\gamma$-lactone 類 の合成 $((p)$ and $(q)) \quad \gamma$-位にキラル中心を持つ $\gamma$-ラ クトン類(e.q., ( 9 ))の $\alpha$ 位への置換基の導入は塩基触媒 の存在下にアルキル化剤あるいは酸化剤によって行わ れ，この際 $\gamma$-置換基の anti 側から選択的に導入され る。また一たん導入された置換基は第二の置換基の導入 によって $\operatorname{syn}$ 側に選択的に押し出される。このことは第 二の求電子剤がプロトンである場合には最初の配置が反 転されることを意味する1。しかしながら求電子的に導 入が困難な官能基, 例えばビニル基やアリール基なども ありこの点の克服を上記グリシドール体( 8 )を用いて

(p) and (q)

\author{
()
}

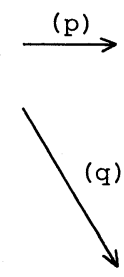

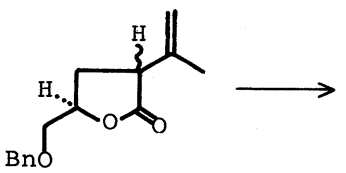

$(\underline{55)}$

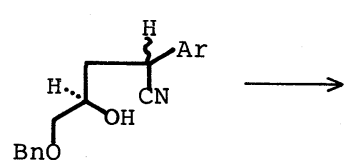

(드)
\解決した。即ちビニル基の場合は $\alpha, \beta$-不飽和エステル から形成させたジアニオン種を，またアリール基の場合 はアリールアセトニトリルアニオン単位をそれぞれグリ シドール体（８）に反応させた後に対応する $\gamma$-ラクトン 誘導体とする手法を確立した1)(スキーム14)。

$(3 S, 5 R$ ) -5-Benzyloxymethyl-3-isopropenyltetrahydrofuran-2-one ${ }^{31)}(15) \mathrm{THF}(300 \mathrm{ml})$ 中 diisopropyl amine $49.24 \mathrm{ml}(352 \mathrm{mmol})$ を溶かし攪拌下に $78^{\circ} \mathrm{C}$ で $n$-BuLi (10\% w/v in hexane) $215.24 \mathrm{ml}$ (336mmol)を加え, $20 \mathrm{~min}$ 後に同温で senecioic acid $16.52 \mathrm{~g}(160 \mathrm{mmol})$ の THF $(100 \mathrm{ml})$ を滴下し，一たん 室温迄上昇させる。再び $-78^{\circ} \mathrm{C} に$ 冷却し, これに 上記 $(S)-(8) 26.24 \mathrm{~g}(160 \mathrm{mmol})$ の $\mathrm{THF}(150 \mathrm{ml})$ 溶液 を滴下し，同温で $30 \mathrm{~min}$, 室温で $30 \mathrm{~min}$ 攪拌する。 混合物に $5 \%$ aq. $\mathrm{NaHCO}_{3}$ を加え, $\mathrm{Et}_{2} \mathrm{O}$ で洗浄す る。水層を $6 \mathrm{~N} \mathrm{HCl}$ で酸性とし $\mathrm{CH}_{2} \mathrm{Cl}_{2}$ で抽出す る。抽出層は brine で洗浄し, 乾燥 $\left(\mathrm{MgSO}_{4}\right)$ し, 溶 媒留去し, 残査を toluene 中 Dean-Stark 装置を付 して $10 \mathrm{~h}$ 還流する。反応混合物を $5 \%$ aq. $\mathrm{NaHCO}_{3}$ で洗浄し, 乾燥 $\left(\mathrm{MgSO}_{4}\right)$ し, 溶媒留去するとラクトね Bno<smiles>[AsH]</smiles>

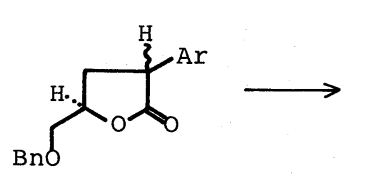

(다)

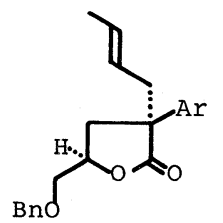

(16)

$\mathrm{Ar}=3,4-(\mathrm{MeO}){ }_{2} \mathrm{C}_{6} \mathrm{H}_{3}^{-}$

Scheme 14

\ンエピマー混合物(55) $32.7 \mathrm{~g}$ を得る。この混合物を THF $(100 \mathrm{ml})$ に溶解し，あらかじめ調製した LDA 溶 液 $[\mathrm{THF}(150 \mathrm{ml})$ 中 diisopropylamine18.6ml $(133 \mathrm{mmol})$ と $n-\mathrm{BuLi}(10 \% \mathrm{w} / \mathrm{v})$ in hexane $85.2 \mathrm{ml}$ $(133 \mathrm{mmol})] に-78^{\circ} \mathrm{C}$ で攪拌下に滴下する。 $-75^{\circ} \mathrm{C}$ で $15 \mathrm{~min}$, 室温で $15 \mathrm{~min}$, 再び $-78^{\circ} \mathrm{C} 15 \mathrm{~min}$ 攪挥 後, これに $10 \% \mathrm{HCl}(120 \mathrm{ml})$ を一挙に加える。室温 になってから brine を加え一度 $\mathrm{Et}_{2} \mathrm{O}$ 抽出し, つい で水層を $\mathrm{CH}_{2} \mathrm{Cl}_{2}$ で抽出する。合わせた抽出層を乾 燥 $\left(\mathrm{MgSO}_{4}\right)$ し, 溶媒留去後シリカゲルカラムクロマ トグラフィーに付し， $(3 S, 5 R)$-lactone 体 (15) $23.2 \mathrm{~g}\left(62 \%\right.$ overall) を得る : $[\alpha]_{\mathrm{D}}-10.52^{\circ}$ (c 5.858,
$\left.\mathrm{CHCl}_{3}\right)$ 。

$(3 R, 5 R)$-5-Benzyloxymethyl-3-[2(E) -butenyl] 3 - (3,4 - dimethoxyphenyl) - tetrahydrofuran - 2 $\operatorname{one}^{32 \mathrm{~b})}(16) \mathrm{THF}(100 \mathrm{ml})$ 中 $n-\operatorname{BuLi}(10 \% \mathrm{w} / \mathrm{v}) 33.6 \mathrm{ml}$ $(52.5 \mathrm{mmol})$ と diisopropylamine $7.36 \mathrm{ml}(52.5 \mathrm{mmol})$ から調 製した LDA 溶液にー $78^{\circ} \mathrm{C}$ で覺汼下に 3,4 dimethoxyphenylacetonitrile $7.75 \mathrm{~g}(43.8 \mathrm{mmol})$ を滴 下し, 同温で $1 \mathrm{~h}$ 䂓抖後, 上記 $(S)-(8) 7.18 \mathrm{~g}$ $(43.8 \mathrm{mmol})$ を一挙に加え, 徐々に室温に戻し $3 \mathrm{~h}$ 攪 拌を続ける。反応液に sat. aq. $\mathrm{NH}_{4} \mathrm{Cl}(40 \mathrm{ml})$ を加え THF 層を分取し, $5 \% \mathrm{HCl}$ と brine で洗浄し, 乾燥 $\left(\mathrm{Na}_{2} \mathrm{SO}_{4}\right)$ 後, 減圧で溶媒を留去しエピマー混合物 
(56) $14.9 \mathrm{~g}$ を得る。これを直ちに $\mathrm{EtOH}(120 \mathrm{ml})$ 中 $\mathrm{KOH}(12 \mathrm{~g})$ と $12 \mathrm{~h}$ 還流する。溶媒留去し残査を水で 希釈し水層を $\mathrm{CH}_{2} \mathrm{Cl}_{2}$ で抽出し, 抽出層は brine で 洗浄 L, 乾燥 $\left(\mathrm{MgSO}_{4}\right)$ 後, 溶媒留去し, 残留物 $(13.5 \mathrm{~g})$ を $5 \% \mathrm{HCl}(100 \mathrm{ml})$ と $\mathrm{EtOH}(150 \mathrm{ml})$ 中で室温 下に $6 \mathrm{~h}$ 攪挥する。 $\mathrm{EtOH}$ を留去し，水層を $\mathrm{CH}_{2} \mathrm{Cl}_{2}$ で抽出し, 抽出層を brine で洗浄し, 乾燥 $\left(\mathrm{Na}_{2} \mathrm{SO}_{4}\right)$ する。溶媒留去後シリカゲルカラムクロ マトグラフィーに付し lactone エピマー混合物 (57) $9.57 \mathrm{~g}\left(63.9 \%\right.$ overall)を得る：mp $91-93^{\circ} \mathrm{C}$ (benzenehexane)。この (57)8.75g (25.6mmol)の THF $(60 \mathrm{ml})$ 溶液を, THF $(100 \mathrm{ml})$ 中 $n-\mathrm{BuLi}(10 \% \mathrm{w} / \mathrm{v}$ in hexane $)$ $32.7 \mathrm{ml}(51.2 \mathrm{mmol})$ と diisopropylamine $7.17 \mathrm{ml}$ $(51.2 \mathrm{mmol})$ から調製した LDA 溶液中に $-78^{\circ} \mathrm{C}$ 攪 拌下に滴下し, $1 \mathrm{~h}$ 後, 同温で $(E)$-crotyl bromide $5.27 \mathrm{ml}(51.2 \mathrm{mmol})$ を一挙に加え, $5 \mathrm{~h}$ 攪拌する。混 合物に sat. aq. $\mathrm{NH}_{4} \mathrm{Cl}(35 \mathrm{ml})$ を加え THF 層を分取 し, $5 \% \mathrm{HCl}$ および brine で洗浄し, 乾燥 $\left(\mathrm{Na}_{2} \mathrm{SO}_{4}\right)$ し, 溶媒留去し, シリカゲルカラムクロマトグラフ イーに付し $\alpha$, $\alpha$-disubstituted lactone (16)7.61g $(75.1 \%)$ を得る: $[\alpha]_{\mathrm{D}}-26.1^{\circ}(\mathrm{c} 2.74, \mathrm{MeOH})$ 。

3. 13. $(2 S, 3 R)-3-[(S)-1,2-D i h y d r o x y e t h y l]-5$-norbornene-2-carboxylic Acid Lactone (17), (2S,3R)および $(2 R, 3 S)$-3-Hydroxymethyl-5-norbornene-2carboxylic Acid Lactone (22) の合成 ( $(r),(y)$, and (z)) すでに(3.8.および3.9.) で述べたようにキラルな nor. bornene 誘導体はビルディングブロックとして極めて有 用性が高い。われわれは先に得た遊離の水酸基を持つ butenolide 体(10)がそのままジエノフィルとして有効に 機能し cyclopentadiene との反応で結晶性の付加体(17) を生成することを見出し, さらに付加体(17)の持つカル

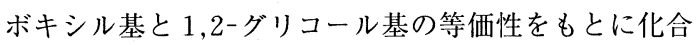
物(22)の両対掌体も合成した ${ }^{27}($ スキーム15)。

$(2 S, 3 R)-3-[(S)-1,2-D i h y d r o x y e t h y l]-5$-norbornene-2-carboxylic Acid Lactone ${ }^{27 b)}(17)$ 上記 $(S)$ butenolide $(10) 1.0 \mathrm{~g}(8.77 \mathrm{mmol})$ と cyclopentadiene $4.4 \mathrm{ml}(52.6 \mathrm{ml})$ の混合物を封管中 $140^{\circ} \mathrm{C}$ で $20 \mathrm{~h}$ 加熱する。混合物からシリカゲルカラムクロマトグ ラフィーによって過剰の cyclopentadiene に由来す る成績体を分離後, benzene-hexane から再結晶し 付加体 (17) $1.14 \mathrm{~g}(72 \%)$ を得る：mp $96-97^{\circ} \mathrm{C}$; $[\alpha]_{\mathrm{D}}{ }^{26}-49.77^{\circ}\left(\mathrm{c} 1.01, \mathrm{CHCl}_{3}\right)$ 。

(2R, 3S) -3-Hydroxymethyl-5-norbornene-2-carboxylic Acid Lactone ${ }^{27 b)}$ (22) 上記 (17) $132 \mathrm{mg}$ $(0.73 \mathrm{mmol})$ を $20 \%$ aq. $\mathrm{KOH}(1 \mathrm{ml})$ と室温下 $10 \mathrm{~min}$ 攪捧し, ついで反応混合物中に $\mathrm{CO}_{2}$ ガスを導入し て $\mathrm{pH} 8 \sim 9$ とする。この溶液に $0^{\circ} \mathrm{C}$ 攪挥下に $\mathrm{NaIO}_{4} 255 \mathrm{mg}(1.1 \mathrm{mmol})$ の水溶液 $(1 \mathrm{ml})$ を加え, さ らに $\mathrm{NaBH}_{4} 81 \mathrm{mg}(2.2 \mathrm{mmol})$ を加える。反応混合物 に $10 \% \mathrm{HCl}$ を加え酸性としてから $\mathrm{CH}_{2} \mathrm{Cl}_{2}$ で抽出 し, 抽出層を brine で洗浄し, 乾燥 $\left(\mathrm{MgSO}_{4}\right)$ する。 溶媒留去しシリカゲルカラムクロマトグラフィーに 付し ( $2 R, 3 S$ )-lactone (22) 60mg (55\%)を得る：mp $65-67^{\circ} \mathrm{C} ;[\alpha]_{\mathrm{D}}{ }^{26-148.20^{\circ}}\left(\mathrm{c} 0.52, \mathrm{CHCl}_{3}\right)$ 。

(2S, 3R) -3-Hydroxymethyl-5-norbornene-2-carboxylic Acid Lactone ${ }^{27 b)}$ (22) 上記付加体 (17) $(\mathrm{r}),(\mathrm{y})$ and $(\mathrm{z})$

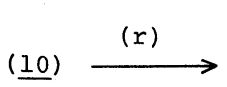

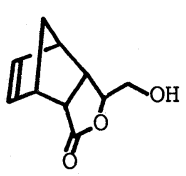

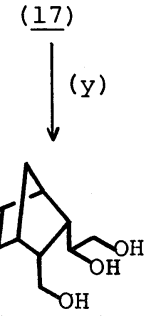

(61)
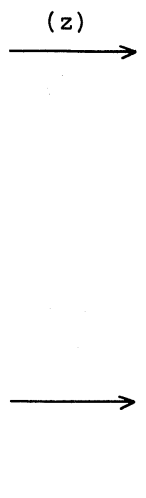

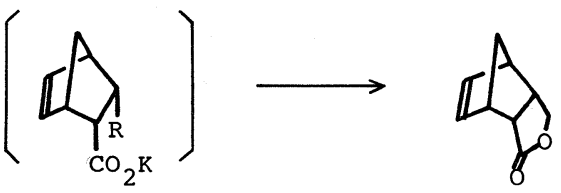

(다) $\mathrm{R}=\mathrm{THOH}_{\mathrm{H}}$

$(2 S, 3 R)-(\underline{22})$

(9) $\mathrm{R}=\mathrm{CHO}$

(60) $\mathrm{R}=\mathrm{CH}_{2} \mathrm{OH}$

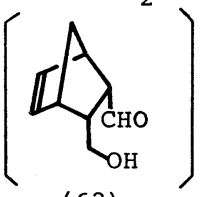

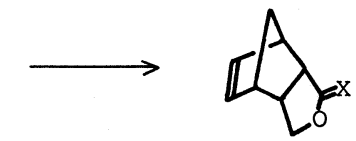

(63) $\mathrm{X}=\mathrm{H}, \mathrm{OH}$ $(2 \mathrm{R}, 3 \mathrm{~S})-(\underline{22}) \quad \mathrm{X}=0$

Scheme 15 
$120 \mathrm{mg}(0.67 \mathrm{mmol})$ を $i \mathrm{PrOH}(1 \mathrm{ml})$ 中 $\mathrm{NaBH}_{4} 25 \mathrm{mg}$ $(0.67 \mathrm{mmol})$ と $1 \mathrm{~h}$ 還流する。溶媒留去し, 残查を $\mathrm{H}_{2} \mathrm{O}(1 \mathrm{ml})$ に溶かし, $0^{\circ} \mathrm{C}$ で攪拌下に $\mathrm{NaIO}_{4} 356 \mathrm{mg}$ $(1.68 \mathrm{mmol})$ の水溶液 $(2 \mathrm{ml})$ を加え, $2 \mathrm{~h}$ 攪拌を続け る。混合物を $\mathrm{CH}_{2} \mathrm{Cl}_{2}$ で抽出し，抽出層を $5 \% \mathrm{aq}$. $\mathrm{NaHCO}_{3}$, brine で洗浄し, 乾燥 $\left(\mathrm{MgSO}_{4}\right)$ する。溶 媒留去し, 残留物をそのまま benzene $(6 \mathrm{ml})$ 中 Feti zon 試薬 $\left(\mathrm{AgCO}_{3}\right.$ on Celite) $680 \mathrm{mg}(\mathrm{ca} .1 .2 \mathrm{~mol})$ と $1 \mathrm{~h}$ 還流する。ろ過後, 溶媒留去しシリカゲルカラムク ロマトグラフィーに付し(2S ,3R )-lactone (22)62mg $(62 \%)$ を得る：mp $65-67^{\circ} \mathrm{C} ;[\alpha]_{\mathrm{D}}{ }^{26}+147.52^{\circ}(\mathrm{c}$ $\left.0.52, \mathrm{CHCl}_{3}\right)$ 。

3. 14. (R) - (Z) -6-Benzyloxy-5-hydroxy-2-hexenoic Acid Lactone (20) および $(3 S, 5 R)-6$ - Benzyloxy-5hydroxy-3-methylhexanoic Acid Lactone (25) の合成 (w) and (cc) 前記 butenolide (10)同様 $\delta$-位にキラル 中心を持つ $\alpha, \beta$-不飽和 $\delta$-ラクトン類もビルディング ブロックとして高い潜在価值を持つ。上述の末端アセチ

(w) and (cc)
(12)

$(\underline{64})$
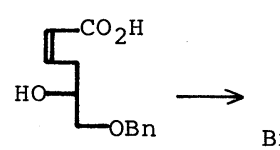

(도)<smiles>O=C1C=CC[C@@H](CO[18OH])O1</smiles>

(20)

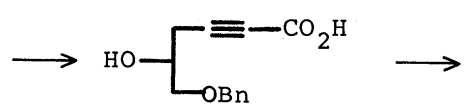

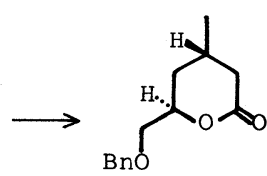

(25)
Scheme 16
レン(12)からこの単位 $(20)$ の合成を行うと共にこれに対 する Michael 型付加が極めて高立体選択的に進行するこ とを見出した ${ }^{33)}($ スキーム16)。

$(R)$ - (Z) -6-Benzyloxy-5-hydroxy-2-hexenoic Acid Lactone $^{33)}(20)$ 上記 $(12) 1.81 \mathrm{~g}(9.50 \mathrm{mmol}) の$ $\mathrm{THF}(50 \mathrm{ml})$ 溶液に $-30^{\circ} \mathrm{C}$, 攪拌下に $n-\mathrm{BuLi}$ $(10 \% \mathrm{w} / \mathrm{v}$ in hexane $) 14.6 \mathrm{ml}(22.8 \mathrm{mmol})$ を加える。 同温で $15 \mathrm{~min}$ 攪拌後 $\mathrm{CO}_{2}$ ガスを導入し $1 \mathrm{~h}$ 攪拌す る。反応混合物に brine $(80 \mathrm{ml})$ を加え, $\mathrm{Et}_{2} \mathrm{O}$ で洗浄 後, 水層を $\mathrm{concHCl}$ で酸性とし, $\mathrm{Et}_{2} \mathrm{O}$ で抽出し, 乾燥 $\left(\mathrm{MgSO}_{4}\right)$ し, 溶媒留去し粗カルボン酸 $(64)$ $2.27 \mathrm{~g}$ を得る。この(64) $1.72 \mathrm{~g}$ を $\operatorname{AcOEt}(30 \mathrm{ml})$ 中 Lindlar 触媒 $(100 \mathrm{mg})$ の存在下に室温下常圧で部分 水素化する $(8.5 \mathrm{~h}) 。$ セライトろ過後, 溶媒留去す ると粗 $(Z)$-カルボン酸 $(65) 1.57 \mathrm{~g}$ を得る。(65) $1.10 \mathrm{~g}$ benzene $(30 \mathrm{ml})$ 溶液中 Dean-Stark 装置を付 して 8.5h 還流後, 反応液を $5 \%$ aq. $\mathrm{NaHCO}_{3}$, brine で洗浄し, 乾燥 $\left(\mathrm{MgSO}_{4}\right)$ し, 溶媒留去後, シリカゲ ルカラムクロマトグラフィーに付しラクトン体 $(20)$ $0.65 \mathrm{~g}(64 \%$ overall from $(12))$ を得る: $[\alpha]_{\mathrm{D}}{ }^{27}+$ $115.07^{\circ}$ (c $\left.1.008, \mathrm{CHCl}_{3}\right)$ 。

(3S, 5R) -6-Benzyloxy-5-hydroxy-3-methylhexanoic Acid Lactone ${ }^{33)}$ (25) $\mathrm{Et}_{2} \mathrm{O}(27 \mathrm{ml})$ 中 $\mathrm{CuI}$ $1.57 \mathrm{~g}(8.24 \mathrm{mmol})$ を懸濁させ，氷冷攪拌下に MeLi $\left(1.09 \mathrm{M}\right.$ in $\left.\mathrm{Et}_{2} \mathrm{O}\right) 15 \mathrm{ml}(16.5 \mathrm{mmol})$ を加え $1 \mathrm{~h}$ 攪挥し て調製した溶液に，同温で上記ラクトン体 $(20)$ $598 \mathrm{mg}(2.75 \mathrm{mmol})$ の $\mathrm{Et}_{2} \mathrm{O}(5 \mathrm{ml})$ 溶液を滴下し $30 \mathrm{~min}$ 攪拌する。混合物に sat. aq. $\mathrm{NH}_{4} \mathrm{Cl}$ を加え, $\mathrm{Et}_{2} \mathrm{O}$ 層 を分取し，水層を $\mathrm{Et}_{2} \mathrm{O}$ でさらに抽出する。合わせ た $\mathrm{Et}_{2} \mathrm{O}$ 層を $5 \%$ aq. $\mathrm{NaHCO}_{3}$ と brine で洗浄し, 乾 燥 $\left(\mathrm{MgSO}_{4}\right)$ 後, 溶媒留去し, シリカゲルカラムクロ

(aa) and (bb)

(18)

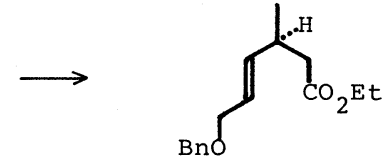

(23)

(19)

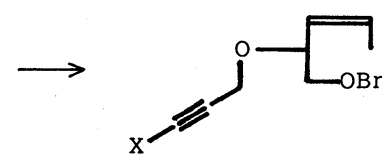

(66) $\mathrm{R}=\mathrm{H}$

(67) $\mathrm{R}=\mathrm{SiMe}_{3}$

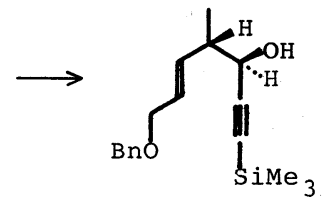

(24) 
マトグラフィーに付し(26) $474 \mathrm{mg}(74 \%)$ を得る： $[\alpha]_{\mathrm{D}}^{25}-33.33^{\circ}\left(\mathrm{c} 1.014, \mathrm{CHCl}_{3}\right)$ 。

3.15. キラル 2 級メチルビルディングブロック類の合 成 ( $(\mathbf{a} \mathbf{a})$ and $(\mathbf{b b}))$ 上述の $E$-拉よび $Z$-配置を持つ 2 種のアリルアルコール異性体(18)抄よび(19)はそれぞれ シグマトロピー転位反応の良い基質となる。両者につい て Claisen 型転位反応 ${ }^{34)}$ および $[2,3]-W i t t i g$ 転位 ${ }^{351}$ 反応 を検討したところ $E$-体 (18)については Claisen 転位 が，一方 Z-体(19)については[2,3]-Wittig 転位反応が 完全なジアステレオ選択性で進行することが判っ た 33.34)。それぞれ得られる成績体は機能性の高い官能基 を持つキラル 2 級メチル単位であり天然物合成のビルデ イングブロックとして高い潜在的価值を持つと思われる (Scheme17)。

Ethyl (S) - (E) -6-Benzyloxy-3-methyl-4-hexenoate ${ }^{33)}$

(23) 上記 $(E)-(18) 2.90 \mathrm{~g}(15.1 \mathrm{mmol})$, triethyl orthoacetate $12.67 \mathrm{~g}(78.1 \mathrm{mmol})$ および pivalic acid $96 \mathrm{mg}(0.94 \mathrm{mmol})$ の混合物を, $140^{\circ} \mathrm{C}$ で留出する低 沸点物を除きながらで $20 \mathrm{~h}$ 加熱する。減圧下過剩 の orthoester を留去し, シリカゲルカラムクロマト グラフィーに付し $(S)$-エステル体 $(23) 3.38 \mathrm{~g}(85 \%)$ を得る : $[\alpha]_{\mathrm{D}}{ }^{28}+17.25^{\circ}\left(\mathrm{c} 5.008, \mathrm{CHCl}_{3}\right)$ 。

$(3 R, 4 S)$ - (E) -7-Benzyloxy-3-hydroxy-4-methyl -1-trimethylsilyl-5-hept-1-yne ${ }^{33)}(24)$ 上記 $(Z)$ アルコール体 $(19) 21.66 \mathrm{~g}(112.8 \mathrm{mmol})$ と propargyl bromide $53.69 \mathrm{~g}(451.3 \mathrm{mmol})$ を $\mathrm{CH}_{3} \mathrm{CN}(500 \mathrm{ml})$ 中 $\mathrm{KF}$ $-\mathrm{Al}_{2} \mathrm{O}_{3}(2: 3 \mathrm{w} / \mathrm{v})$ コンプレックス $(144.3 \mathrm{~g})$ と室温下 に $14 \mathrm{~h}$ 攪拌懸濁する。万過後, 濃縮しシリカゲル カラムクロマトグラフィーに付しエーテル体(66) $18.19 \mathrm{~g}(70 \%)$ を得る： bp $130^{\circ} \mathrm{C}$ (0.2torr); $[\alpha]_{\mathrm{D}}^{25}-85.38^{\circ}$ (c 1.04, $\left.\mathrm{CHCl}_{3}\right)$ 。この $(66) 10.0 \mathrm{~g}$ $(43.48 \mathrm{mmol})$ の $\mathrm{THF}(150 \mathrm{ml})$ の溶液に水冷, 㩭拌下 に $\mathrm{EtMgBr}(1.3 \mathrm{M}$ in THF $) 83.61 \mathrm{ml}(108.7 \mathrm{mmol})$ を加 え,3h 後,trimethylsilylchloride $14.17 \mathrm{~g}(130.4 \mathrm{mmol})$ を加 え 10 min 攪挥する。反応混合物に sat. aq. $\mathrm{NH}_{4} \mathrm{Cl}$ $(50 \mathrm{ml})$ を加え， $\mathrm{Et}_{2} \mathrm{O}$ で抽出する。抽出層を sat. aq. $\mathrm{NaHCO}_{3}$ と brine で洗浄し, 乾燥 $\left(\mathrm{MgSO}_{4}\right)$ L, 溶媒 留去後シリカゲルカラムクロマトグラフィーに付し シリル体 (67) $12.23 \mathrm{~g}$ (93\%) を得る：bp $130^{\circ} \mathrm{C}$ $(0.2$ torr $) ;[\alpha]_{\mathrm{D}}{ }^{27}-80.74^{\circ}$ (c $\left.1.018, \mathrm{CHCl}_{3}\right)_{0}$ ここの (67) $100 \mathrm{mg}(0.331 \mathrm{mmol})$ の $\mathrm{THF}(2 \mathrm{ml})$ 溶液に $-70^{\circ} \mathrm{C}$ で攪拌下に $n$ - BuLi $(10 \% \mathrm{w} / \mathrm{v}$ in hexane) $0.39 \mathrm{ml}$ $(0.60 \mathrm{mmol})$ を加え，同温で $4 \mathrm{~h}$ 攪拌する。反応混合 物に sat. aq. $\mathrm{NH}_{4} \mathrm{Cl}$ を加え, $\mathrm{Et}_{2} \mathrm{O}$ で抽出し, 抽出層 を sat. aq. $\mathrm{NaHCO}_{3}$ と brine で洗浄し, 乾燥 $\left(\mathrm{MgSO}_{4}\right)$
し，溶媒留去後シリカゲルカラムクロマトグラフ イーに付し転位体(24)73.4mg(73\%)を得る：[ $\alpha]_{\mathrm{D}}{ }^{24}+$ $18.91^{\circ}$ (c $\left.0.64, \mathrm{CHCl}_{3}\right)$ 。

\section{4. おわりに}

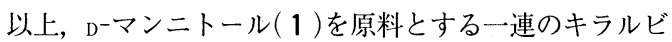
ルディングブロックの合成に関して実施例を中心として 示した。はじめにも述べた様に本稿に示した例はいずれ も私共が実施した例だけに限定され，しかも本質的には D ーマンニトール $(1)$ をグリセロール 2 量体として見なした 変換だけに止まるものであるが，いずれも困難なく量的 合成を行い得るものでありキラルビルディングブロック として有効に活用出来るものと考えている。本稿に示し た例はさらに多くの改善と展開の余地があるが, これら の例が今後 D-マンニトール（1) 抢よび関連する化合物を キラル原料として活用されんとする方々の参考となれば 幸いである。

最後に，これら地味な仕事にも関わらず全力を注いで くれた東北大学薬学部薬品合成化学教室の諸氏(文献中に 記載)に深く感謝します。また本研究は一部文部省科学研 究費の助成を受けた。ここに記して謝意を表します。

(昭和62年 5 月11日受理)

\section{文献}

1a)高野誠一，小笠原国郎，有合化，40，1037 (1982)

b)高野誠一，小笠原国郎，月刊薬事，26，79 (1984)

c)S. Takano, Pure Appl. Chem., 59, 353 (1987)

2)例えば笠井尚哉，他，特願59-254607，60-179096。

3a)J.M. Klunder, S. Y. Ko, K. B. Sharpless, J. Org. Chem., 51, 3710 (1986)

b)S. Y. Ko, K. B. Sharpless, ibid., 51, 5413 (1986)

c)R. M. Hanson, K. B. Sharpless, ibid., 51, 1922 (1986)

4)他の多くの例については以下の文献を参照されたい。

a) A. Vasella, Modem Synthetic Methods, Edn. R. Scheffold, Salle Verlag, Frankfurt am Main, 1980, Vol. 2, pp. 173267

b) S. Hanessian, Total Synthesis of Natural Products : The "Chiron" Approach, Pergamon Press, Oxford, 1983

c)J. W. Scott, Asymmetric Synthesis, Edn, J. D. Morrison, J.

W. Scott, Academic Press, Orlando, 1984, pp. 1-261

d)T. O. Inch, Tetrahedron, 40, 3161 (1984)

e)J. Jurczak, S. Pikul, T. Bauer, ibid., 42, 447 (1986)

5)E. Baer, Biochemical Preparations, 2, 31 (1952)

6)L. F. Wiggins, J. Chem. Soc., 1946, 13

7) L. J. Rubin, H. A. Lardy, H. O. L. Fischer, J. Am. Chem. Soc., 74, 425 (1952)

8) Cf. J. Kuszmann, E. Tomori, I. Meerwald, Carbohydr. Res., 128, 87 (1984) 
9)S. Takano, E. Goto, M. Hirama, K. Ogasawara, Heterocycles, 16, 381 (1981)

10)適切な条件下ではもちろん 1,2- $O$-isopropylidene- $(R)$ -glyceraldehyde (29)の充分な量の単離は可能である : E. Baer, H. O. L. Fischer, J. Am. Chem. Soc., 61, 761 (1930), ただしこの方法においては酸化剤として用い られている四酢酸鉛から副生する酢酸によって29の 分解が促進される。この改良方法として炭酸カリウ ムを共存させて酢酸を中和する手法が見出されてい る (G. Stork, T. Takahashi, 未発表デー夕)。即ち, 反 応系に 2 モル等量の炭酸カリウムを共存させて 26 の 開裂を行い, セライトでろ過後, 直ちに蒸留するこ とによって 29 を大量に得ることが出来る。本改良法 をお知らせ頂いた東工大高橋孝志博士に感謝致しま す。

11) S. Takano, A. Kurotaki, M. Takahashi, K. Ogasawara, Synthesis, 1986, 403

12)高野誠一，杉原多公通，小笠原国郎，未発表デー夕

13)S. Takano, A. Kurotaki, K. Ogasawara, Synthesis, in press

14) S. Takano, K. Seya, E. Goto, M. Hirama, K. Ogasawara, Symthesis, 1983, 116

15) S. Takano, M. Akiyama, S. Sato, K. Ogasawara, Chem. Lett., 1983, 1593

16)S. Takano, A. Kurotaki, Y. Sekiguchi, S. Satoh, M. Hirama, K. Ogasawara, Synthesis, 1986, 811

17 a ) S. Takano, M. Akiyama, K. Ogasawara, Chem. Pharm. Bull., 32, 791 (1984)

b )秋山正司，修士論文，東北大学，1985

18) A. K. M. Anisuzzaman, L. N. Owen, J. Chem. Soc., [C] 1967, 1021

19) Cf. J. Gelas, Advan. Carbohydr. Chem. Biochem., 39, 71 (1982)

20) S. Takano, M. Akiyama, K. Ogasawara, Synthesis, 1985, 503

21) M. Taniguchi, K. Koga, S. Yamada, Tetrahedron, 30, 3547 (1984)

22a) K. Tomioka, T. Ishiguro, K. Koga, J. Chem. Soc., Chem. Commun., 1979, 652 b) K. Tomioka, T. Ishiguro, Y. Iitaka, K. Koga, Tethahedron, 40, 1303 (1984)

23a) P. Camps, J. Font, O. Ponsati, Tetrahedron Lett., 1981, 1471

b)P. Camps, J. Cardellach, J. Font, R. M. Ortuno, O. Ponsati, Tetrahedron, 38, 2395 (1982); 39, 395 (1983)

24) R. E. Ireland, R. C. Anderson, R. Badoud, B. J. Fitzsimmons, G. J. McGarvey, S. Thaisrivongs, C. S. Wilkox, J. Am. Chem. Soc., 105, 1988 (1983)

25) S. Takano, M. Morimoto, K. Ogasawara, Synthesis, 1984, 843

26)最近，D-マンニトール(1)からブテノリド体 $(10)$ の興 味ある合成法も開発されたが，グリセルアルデヒド 体(29)の単離を必要とし10), 大量合成には不適と思わ れる。

a) G. A. Danilova, V. I. Mel'nikova, K. K. Pivnitsky, Tetrahedron Lett., 27, 2489 (1986)

b)B. Hafele, V. Jager, Liebigs Ann. Chem., 1987, 85

27a)S. Takano, A. Kurotaki, K. Ogasawara, Tetrahedron Lett., 28, 3991 (1987)

b)黒滝綾子, 修士論文, 東北大学, 1987

28)S. Takano, Y. Sekiguchi, N. Sato, K. Ogasawara, Synthesis, 1987, 139

29)S. Takano, M. Akiyama, K. Ogasawara, J. Chem. Soc., Perkin Trans. I, 1985, 2447

30)高野誠一, 大川武彦，小笠原国郎，未発表デー夕

31)S. Takano, M. Tanaka, K. Seo, M. Hirama, K. Ogasawara, J. Org. Chem., 50, 931 (1985)

32 a )S. Takano, Y. Imamura, K. Ogasawara, Tetrahedron Lett., 22, 4479 (1981)

b)今村葉子，修士論文，東北大学，1982

33)関口喜功, 修士論文, 東北大学, 1987

34) Cf. W. S. Johnson, L. Werthemann, W. R. Bartlett, T. Brocksom, T. Li, DJ. Faulkner, M. R. Petersen, J. Am. Chem. Soc., 92, 741 (1970)

35)Cf. T. Nakai, K. Mikami, Chem. Rev., 86, 885 (1986)

36)S. Takano, Y. Sekiguchi, K. Ogasawara, J. Chem. Soc., Chem. Commun., 1987, 55 